\title{
Skeletal Reorganization Divergence of N-Sulfonyl Ynamides
}

\section{Linwei Zeng}

Zhejiang University

\section{Yuxin Lin}

Zhejiang University

Jiaming Li

Zhejiang University

\section{Hironao Sajiki}

Gifu Pharmaceutical University https://orcid.org/0000-0003-2792-6826

\section{Sunliang Cui ( $\nabla$ slcui@zju.edu.cn )}

Zhejiang University

\section{Article}

Keywords:

Posted Date: July 14th, 2020

DOI: https://doi.org/10.21203/rs.3.rs-38522/v1

License: (c) (1) This work is licensed under a Creative Commons Attribution 4.0 International License. Read Full License

Version of Record: A version of this preprint was published at Nature Communications on November 6th, 2020. See the published version at https://doi.org/10.1038/s41467-020-19467-5. 


\title{
Skeletal Reorganization Divergence of $N$-Sulfonyl Ynamides
}

\author{
Linwei Zeng ${ }^{1}$, Yuxin Lin ${ }^{1}$, Jiaming $\mathrm{Li}^{1}$, Hironao Sajiki² , \& Sunliang Cui ${ }^{1 *}$
}

${ }^{1}$ Institute of Drug Discovery and Design, College of Pharmaceutical Sciences, Zhejiang University, 866 Yuhangtang Road, Hangzhou 310058, China. E-mail: slcui@zju.edu.cn

${ }^{2}$ Laboratory of Organic Chemistry, Gifu Pharmaceutical University, Gifu 501-1196, Japan

Abstract: Skeletal reorganization is a type of intriguing processes for their interesting mechanism, high atom-economy and synthetic versatility. Herein, we describe an unusual skeletal reorganization divergence of $\mathrm{N}$-sulfonyl ynamides. Upon treatment with lithium diisopropylamine (LDA), the $\mathrm{N}$-sulfonyl ynamides could undergo a skeletal reorganization to deliver thiete sulfones, while the additional use of DMPU would shift the process to furnish propargyl sulfonamides. Mechanistically, these processes are proposed to initiate from a lithiation/cyclization cascade, and the following ligand-dependent 1,3-sulfonyl migration or $\beta$-elimination would constitute the divergence. Therefore, this protocol not only represents a new skeletal reorganization mode, but also provides a facile access to privileged molecules from the easily accessible ynamides.

Skeletal reorganization is a type of process involving multiple bonds cleavage and formation for molecule framework reassembly (Fig. 1a) ${ }^{1-2}$. Owing to the intriguing reaction mechanism, high atomeconomy property and capability of accessing complex and synthetically challenging molecules, the skeletal reorganization process has attracted considerable attention and also been widely applied in organic synthesis toward diverse carbocyclic and heterocyclic compounds ${ }^{3-5}$. For example, a variety of transition-metal-catalyzed skeletal reorganizations of enynes have been explored for efficient synthesis of polycyclic compounds ${ }^{6-10}$. Recently, Sun and coworkers discovered an unusual skeletal reorganization of oxetane for the synthesis of 1,2-dihydroquinolines (Fig. 1b) ${ }^{11}$. Meanwhile, Liu and coworkers 
established a skeletal reorganization protocol of olefine via a radical-initiated cyclization/1,n $(n=3,4,5)$ vinyl migration cascade for accessing medium- and large-sized cycles which are ubiquitous structural motifs in natural products and pharmaceutical agents (Fig. 1c) ${ }^{12}$. Very recently, Zhu and coworkers reported a novel skeletal reorganization of kojic acid or maltol-derived alkynes under Indium-catalysis, which provided an expeditious access to valuable hydroxylated benzofurans (Fig. 1d) ${ }^{13}$. Despite these advances, the investigation of skeletal reorganizations toward synthetically challenging and biologically interesting molecules remains continuous interesting and important.

a) Skeletal reorganization

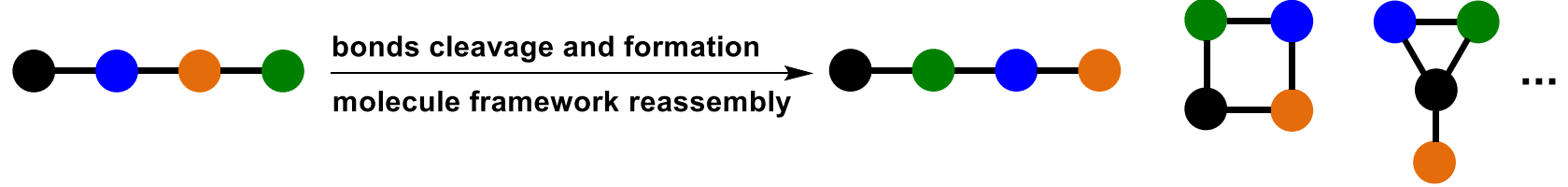

b) Sun's work<smiles>[R]C1=Cc2cc[R1]([H])cc2N([R])C1</smiles>

c) Liu's work

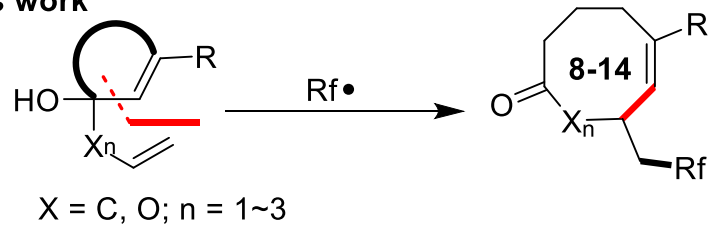

d) Zhu's work<smiles>[R]CC#Cc1c([R])oc(C[R])c([R])c1=O</smiles>

kojic acid-derived<smiles>[R6]CC#Cc1c(C[R])occc1=O</smiles>

maltol-derived

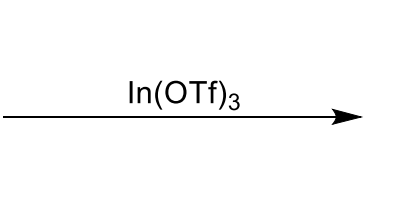<smiles>[R]c1cc2c([R])c([R])c(O)c([Z1])c2o1</smiles><smiles>[R]c1cc2c(O)c([R])ccc2o1</smiles>
hydroxylated benzofurans<smiles></smiles>

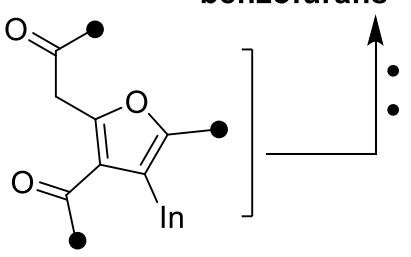

Fig. 1 Skeletal reorganization. a Skeletal reorganization. b In-catalyzed skeletal reorganization of oxetanes.

c Radical-initiated skeletal reorganization of olefines. d In-catalyzed skeletal reorganization of kojic acid- or maltol-derived alkynes. 
The four-membered sulfur-containing heterocycles, such as thiete sulfones, thietane sulfone and thietanes, are type of strained small ring compounds which have found wide applications in the discovery

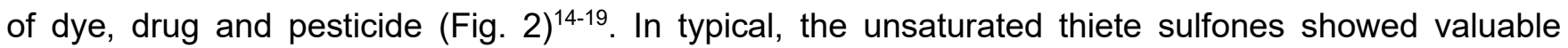
synthetic utility in organic synthesis. For example, thiete sulfones could be used as dienophiles in the Diels-Alder reaction with tetraphenyl cyclopentadienones or isobenzofurans for accessing bridged and fused-ring compounds ${ }^{20-22}$. Moreover, they could participate [3+2] cycloadditions with diazo compounds or nitrile oxides for synthesis of heterocycles ${ }^{23-24}$. Recently, thiete sulfones have been investigated in $\mathrm{C}-\mathrm{H}$ functionalization to establish axially chiral molecules and macrocyclic compounds ${ }^{25-26}$. However, the conventional synthesis of thiete sulfones relies on multi-step routes and also suffers from narrow scope ${ }^{27-}$ 32. Therefore, it would be interesting to explore a distinct and efficient approach to functionalized thiete sulfones.

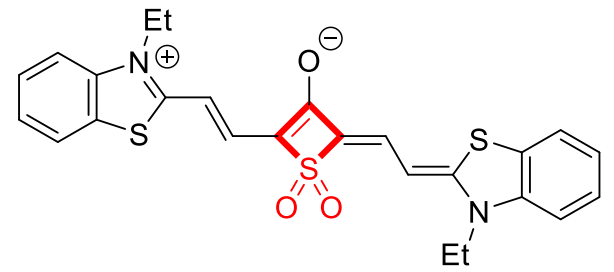

Cyanine dye

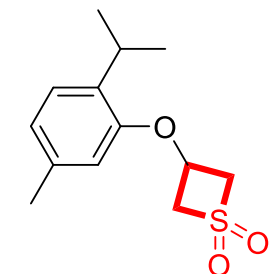

Antidepressant agent

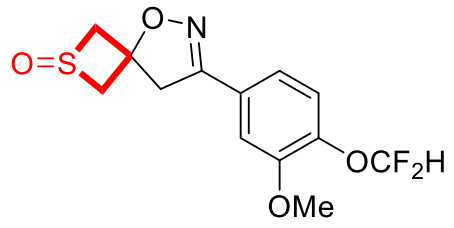

Phosphodiesterase inhibitor

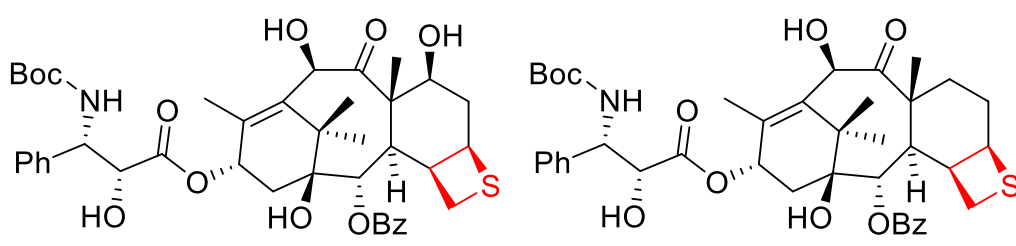

Taxol derivatives<smiles>Cc1cc(C2=NOC(c3cc(Cl)cc(Cl)c3)(c3ccc(C(=O)NC4CSC4)c(F)c3)C2)ccc1C(F)(F)F</smiles>

Pesticide

Fig. 2 Representative molecules containing the structures of sulfur-containing four-membered ring.

Ynamides are type of $\mathrm{N}$-substituted electron rich alkynes which exhibit unique chemical properties and serve as versatile synthons in organic synthesis ${ }^{33-42}$. For example, ynamides could act as flexible cyclization partners in heterocycle synthesis ${ }^{43-45}$, carbene precursors ${ }^{46-49}$ and enamides precursors ${ }^{50-51}$, racemization-free coupling reagents for peptide and macrolide synthesis ${ }^{52-54}$, C2 building blocks of 
multicomponent reactions (MCRs) ${ }^{55-57}$. In recent years, the intramolecular cyclizations of ynamides including transition-metal-catalyzed and Brønsted acid-catalyzed nucleophilic cyclizations, anionic cyclizations and radical cyclizations, have been extensively investigated for synthesis of $N$-heterocycles (Fig. 3a) ${ }^{58-61}$. However, the skeletal reorganization of ynamides is rarely reported. In 2012, Evano and coworkers reported a s-BuLi mediated skeletal reorganization of $\mathrm{N}$-Boc ynamides for de novo synthesis of 1,4-dihydropyridines and pyridines, which invoked a process of carbonyl-directed deprotonation and anionic 6 -endo-dig cyclization (Fig. 3b) ${ }^{62}$. Encouraged by these, we hypothesized that the deprotonation at the a-position of sulfonyl moiety of $\mathrm{N}$-sulfonyl ynamides might initiate an anionic 4-exo-dig or 5-endodig cyclization to deliver cyclic sulfonamides which are privileged structures in medicinal chemistry (Fig. 3c) ${ }^{63-64}$. In continuation of our interests in ynamide chemistry ${ }^{55-57,65}$, herein we would like to report an unprecedented skeletal reorganization divergence of $\mathrm{N}$-sulfonyl ynamides for selective entry to thiete sulfones and propargyl sulfonamides (Fig. 3d). 
a) Intramolecular cyclizations of ynamides

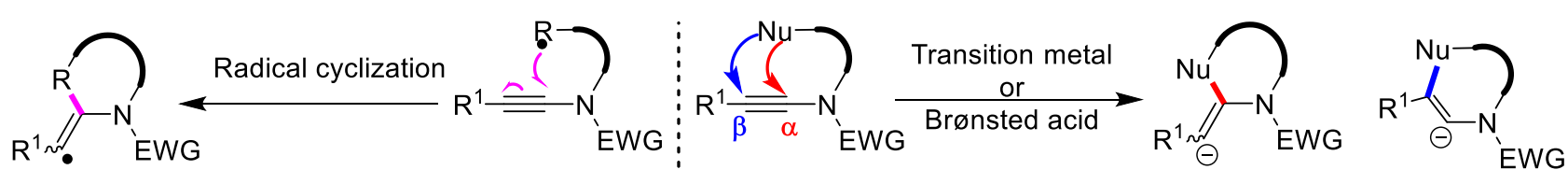
(EWG = electron-withdrawing group)

b) Evano's work: skeletal reorganization of $\boldsymbol{N}$-Boc ynamides

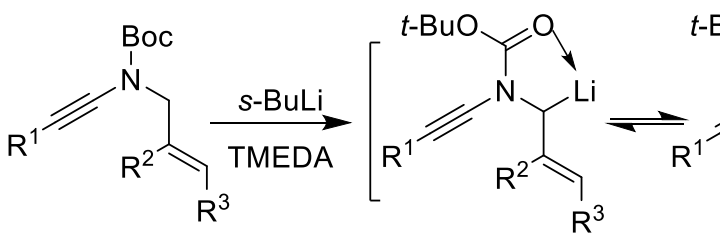<smiles>[R]C=CC([R])C([R])=CN(C#[Y])C(=O)OC(C)(C)C</smiles><smiles>[R1]C#CN(/C=C(/[R])C([R])[Z1]#C)C(=O)OCC(C)(C)C</smiles><smiles>[R]C1=CN(C(=O)OC(C)(C)[O-])C=C([R])C1[R]</smiles>
6-endo-dig

c) Our initial hypothesis<smiles>[R]C#CN([R])S(=O)(=O)C([R3])[R]</smiles>

d) This work: skeletal reorganization divergence of $\mathbf{N}$-sulfonyl ynamides

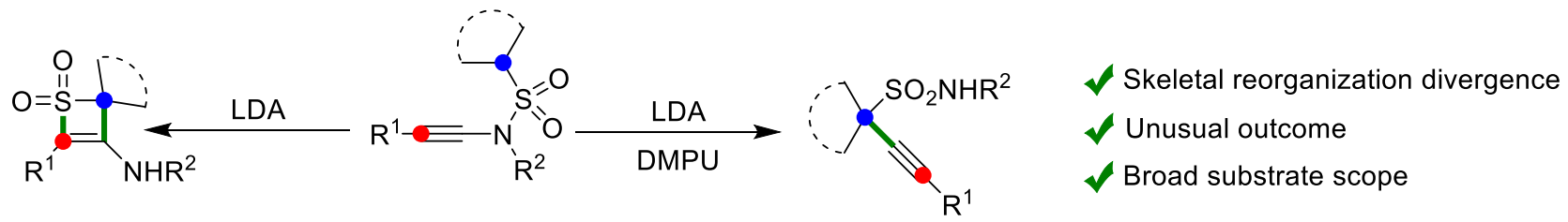

Fig. 3 Skeletal reorganization of ynamides. a. Intramolecular cyclizations of ynamides. b. Skeletal reorganization of $N$-Boc ynamides. c. Initial hypothesis. d. Skeletal reorganization divergence of $N$-sulfonyl ynamides.

\section{Results}

\section{Reaction optimization.}

We commenced our study by using $N$-sulfonyl ynamide 1a and lithium base to investigate this reaction. As shown in Table 1, various bases were employed to treat with 1a in THF at low temperature. We initially set the reaction using $n$-BuLi at $-40^{\circ} \mathrm{C}$ for 1 hour and then treated with $\mathrm{MeOH}$, and a new 
major product $\mathbf{2 a}$ and a minor product $\mathbf{3 a}$ were observed (entry 1). The standard analysis, including ${ }^{1} \mathrm{HNMR},{ }^{13} \mathrm{CNMR}$ and mass spectroscopy, was not able to identify these compounds. Gratifyingly, the X-ray analysis showed that $\mathbf{2 a}$ was a thiete sulfone and 3a was a propargyl sulfonamide, indicating an unusual skeletal reorganization occurring. This unexpected outcome prompted us to optimize the reaction. The next survey of lithium bases showed that LDA was superior to give $2 \mathbf{a}$ in $72 \%$ yield (entry 2), while the utilization of LiHMDS would decrease the yield to $31 \%$ (entry 3). The use of NaHMDS and KHMDS as base could only give $\mathbf{3 a}$ in very low yield (entry 4-5). The next screening of bases such as $\mathrm{NaH}, \mathrm{DBU}$ and TEA showed inferior to shut down the reactivity even at room temperature, and 1a was recovered (entries 6-8). When LDA was used as base and the temperature was varied to $0{ }^{\circ} \mathrm{C}$ or $-78^{\circ} \mathrm{C}$, the yield of $\mathbf{2 a}$ would slightly decrease (entries $9-10$ ). Considering that lithiation was involved in this process, we tried to add ligands to increase the yield. The next using of TMEDA ( $N, N_{,}, N^{\prime}, N^{\prime}-$ tetramethylethylenediamine) as ligand showed no improvement (entry 11). Interestingly, the utilization of DMPU (1,3-dimethyl-tetrahydropyrimidin-2(1H)-one) as ligand would give $3 \mathbf{a}$ in good yield exclusively (entry $12,79 \%$ yield). Therefore, the skeletal reorganization is divergent and could be determined by ligand.

Table 1. Reaction Optimizationa.
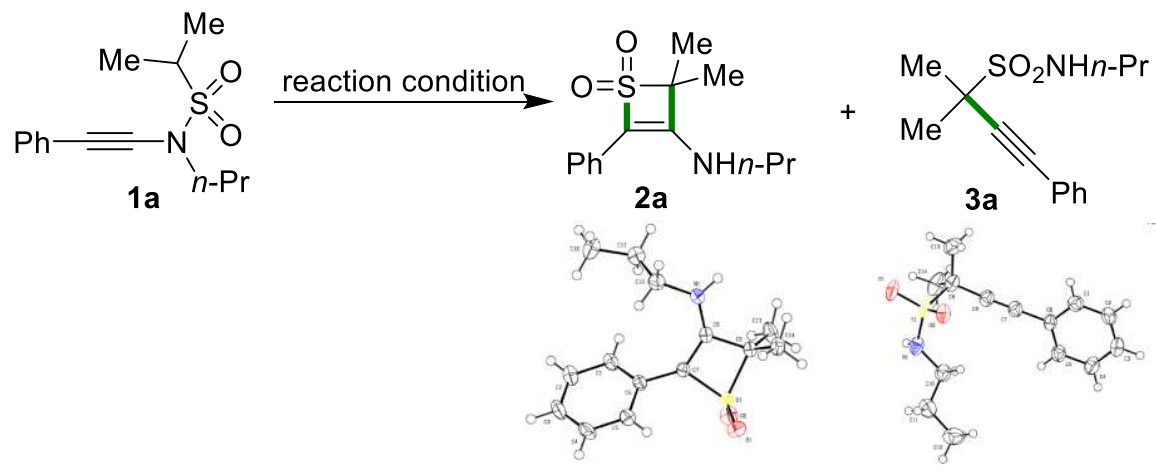

\begin{tabular}{lllccc}
\hline Entry & Base & Additive & Solvent & $\mathrm{T}$ & \multicolumn{2}{c}{${\text { Yield }(\%)^{\mathrm{b}}}^{2}$} & $\left.{ }^{\circ} \mathrm{C}\right]$ & $\mathbf{2 a}$ & $\mathbf{3 a}$ \\
\cline { 3 - 5 } & & & & &
\end{tabular}




\begin{tabular}{lllllll}
\hline 1 & $n-B u L i$ & none & THF & -40 & 60 & 19 \\
2 & LDA & none & THF & -40 & 72 & 18 \\
3 & LiHMDS & none & THF & -40 & 31 & 0 \\
4 & NaHMDS & none & THF & -40 & 0 & 14 \\
5 & KHMDS & none & THF & -40 & 0 & 16 \\
6 & NaH & none & THF & 25 & 0 & 0 \\
7 & DBU & none & THF & 25 & 0 & 0 \\
8 & TEA & none & THF & 25 & 0 & 0 \\
9 & LDA & none & THF & 0 & 68 & 19 \\
10 & LDA & none & THF & -78 & 65 & 21 \\
11 & LDA & TMEDA & THF & -40 & 63 & 16 \\
12 & LDA & DMPU & THF & -40 & trace & 79 \\
\hline
\end{tabular}

aReaction conditions: $1 \mathrm{a}(0.2 \mathrm{mmol})$, base $(0.3 \mathrm{mmol})$, additive $(0.5 \mathrm{mmol})$, THF $(2 \mathrm{~mL}), 1 \mathrm{hr}$, then $\mathrm{MeOH}$ (0.1 mL). For details, see Supplementary.

blsolated yields.

Reaction scope study. With the optimized reaction conditions in hand, we next tested the substrate scope of this skeletal reorganization divergence. The starting material $\mathrm{N}$-sulfonyl ynamides could be easily prepared by coupling of sulfonamides and alkynyl bromides. As shown in Fig. 4, various ynamides 1 could participate well in this skeletal reorganization, leading to the corresponding thiete sulfones 2 in moderate to good yields. Diverse substitutions on the amino group of ynamides, including $n$-butyl, benzyl, i-propyl, cyclopentanyl and thiophene-3-ethyl, were found tolerable in this process $(\mathbf{2} \mathbf{b}-\mathbf{2} \mathbf{d})$. The $(S)-1$ phenylethyl amine derived ynamide $\mathbf{1 g}$ could also engage in this reaction to give the chiral moiety tethered thiete sulfone $\mathbf{2 g}$ in a moderate $56 \%$ yield. Other functional groups, such as alkene and protected alcohol, were also found compatible in this reorganization process to give the corresponding products $(\mathbf{2} \mathbf{h}$ and $\mathbf{2} \mathbf{i})$, which might offer ample opportunities for the further derivatization. In addition, the 
aniline derived ynamide (1j) was also applicable to deliver the desired product $\mathbf{2} \mathbf{j}$ in $77 \%$ yield. The structure of $\mathbf{2} \mathbf{j}$ was further confirmed by X-ray diffraction (for more details, see Supplementary). For the variation of sulfonyl groups, a variety of substitutions were also tested and found amenable in this process to access functionalized thiete sulfones (2k-2q). In detail, $N$-methylsulfonyl and $N$-benzylsulfonyl ynamides could reorganize to corresponding thiete sulfones in moderate yield $(\mathbf{2 k - 2 m})$, and the structure of 2k was confirmed by X-ray diffraction (for more details, see Supplementary). When $N$ cycloalkylsulfonyl ynamides like $N$-cyclopentanylsulfonyl ynamides and $N$-cyclohexanylsulfonyl ynamides were used, the skeletal reorganization could deliver spiro-fused thiete sulfones in moderate to good yields $(\mathbf{2 n - 2 q )}$, and the structure of $\mathbf{2 q}$ was also verified by X-ray diffraction (for more details, see Supplementary). With respect of the substitution at the $\beta$-position of ynamides, a set of aryl groups functionalized with 2-chloro, 3-methyl, 4-methyl, 4-pentyl, 4-methoxy, 4-fluoro or 4-chloro were tolerable to furnish the corresponding products in good yields $(2 \mathbf{r}-2 \mathbf{x})$, and these substituents did not show any significant electronic and steric effects with the yields. Other aryl groups, including 2-naphthyl, 3-pyridinyl and thiophene-2-yl, were suitable in this process to produce the products successfully $\left(2 \mathbf{y}-\mathbf{2 a} \mathbf{a}^{\prime}\right)$, and the structure of $\mathbf{2 a}$ ' was confirmed by X-ray analysis (for more details see Supplementary). Meanwhile, the cyclohexenyl substituted ynamide $\mathbf{1}$ d' could smoothly transform to the corresponding product $\mathbf{2} \mathbf{b}$ ' in $51 \%$ yield. Notably, silyl substitution was compatible with the process as well. For example, the TIPSsubstituted ynamide $1 \mathbf{e}^{\prime}$ could reorganize to product $\mathbf{2} \mathbf{c}^{\prime}$ in $70 \%$ yield with retention of TIPS group, while the TMS-substituted ynamide 1f' could transformed to product $\mathbf{2} \mathbf{d}^{\prime}$ in a remarkable $94 \%$ yield accompanied with TMS desilylation. Since the amino-containing full-substituted thiete sulfones are synthetically challenging ${ }^{66}$, this skeletal reorganization of ynamides provides a robust and efficient approach toward these molecules with the achievement of structural diversity and molecule complexity. 


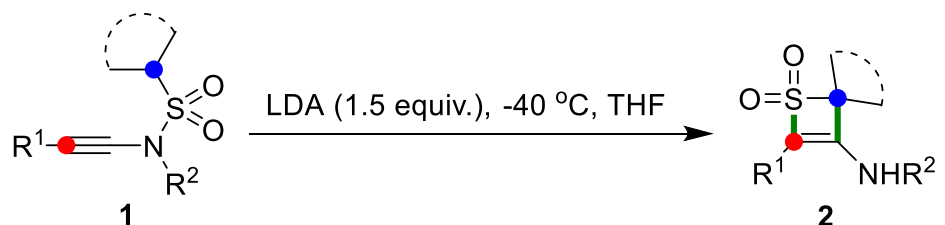

\section{- Scope of amine}

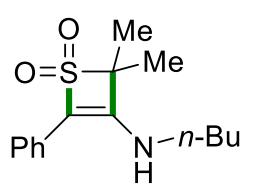

2b, $70 \%$

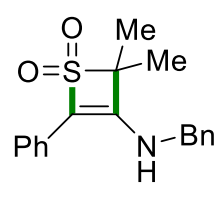

2c, $85 \%$

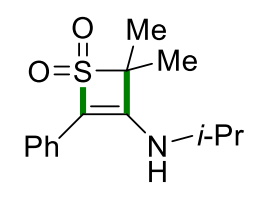

2d, $65 \%$

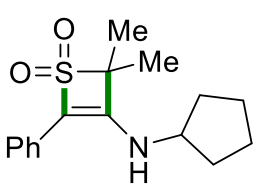

2e, $60 \%$

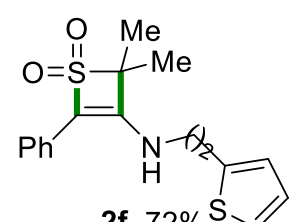

2f, $72 \% \mathrm{~S} \backslash$<smiles>CC(NC1=C(c2ccccc2)C(C)(C)S1(=O)=O)c1ccccc1</smiles>

2g, $56 \%$<smiles>C/C=C\CNC1=C(c2ccccc2)C(C)(C)S1(=O)=O</smiles>

2h, $78 \%$<smiles>CCNC1=C(c2ccccc2)C(C)(C)S1(=O)=O</smiles>

$\mathbf{2 i}, 81 \%$ OTBS

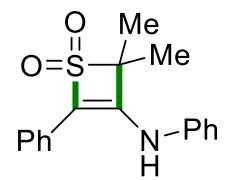

2j, $77 \%$

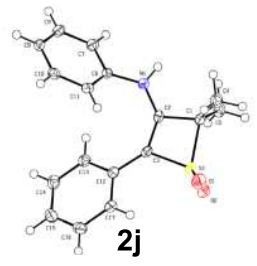

- Scope of sulfonyl<smiles>CNC1=C(c2ccccc2)S(=O)(=O)C1</smiles>

2k, $54 \%^{\mathrm{a}}$

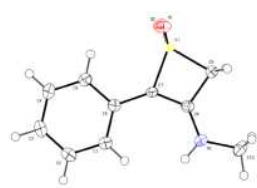

2k<smiles>CCCCNC1=C(c2ccccc2)S(=O)(=O)C1</smiles><smiles>O=S1(=O)C(c2ccccc2)=C(NCc2ccccc2)C1c1ccccc1</smiles>

$2 \mathrm{~m}, 54 \%^{\mathrm{a}}$

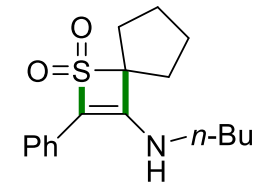

2n, $43 \%$

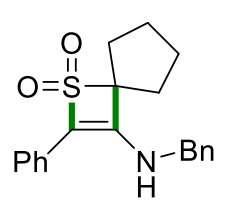

2o, $81 \%$

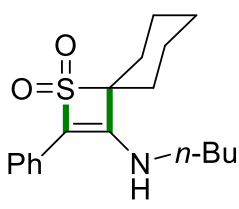

$2 p, 43 \%$

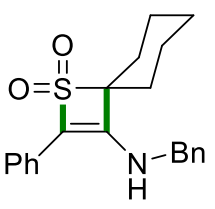

2q, $74 \%$

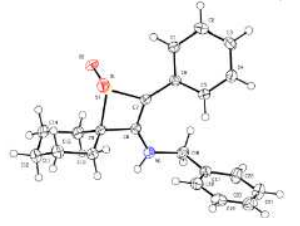

$2 q$

\section{- Scope of alkyne}<smiles>[R]Cc1ccccc1C1=C(NCc2ccccc2)C(C)(C)S1(=O)=O</smiles>

$2 r, R=2-\mathrm{Cl}, 67 \%$ 2s, $\mathrm{R}=3-\mathrm{Me}, 74 \%$ 2t, $\mathrm{R}=4-\mathrm{Me}, 63 \%$

2u, R = 4-pentyl, 74\% $2 v, R=4-O M e, 70 \%$ $2 w, R=4-F, 78 \%$ 2x, $\mathrm{R}=4-\mathrm{Cl}, 85 \%$

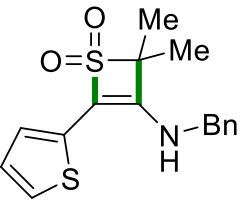

2a', $54 \%$

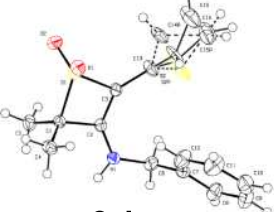

$2 a^{\prime}$<smiles>CC(C)(C)OC(=O)NC1=C(c2ccc3ccccc3c2)S(=O)(=O)C1(C)C</smiles><smiles>CC(C)(C)[13C](C)(C)C</smiles><smiles>CC(C)SC1=C(NCc2ccccc2)C(C)(C)S1(=O)=O</smiles><smiles>Cc1ccccc1NC1=CS(=O)(=O)C1(C)C</smiles>

2b', $51 \%$

2d', 94\% ${ }^{\text {b Me }}$

Fig. 4. Scope of thiete sulfones. Standard condition: $1(0.2 \mathrm{mmol}), \operatorname{LDA}(0.3 \mathrm{mmol}), \operatorname{THF}(2 \mathrm{~mL}),-40^{\circ} \mathrm{C}, 1$ $\mathrm{hr}$, then treated with $\mathrm{MeOH}(0.1 \mathrm{~mL})$. Yields refer to isolated products. ${ }^{\mathrm{a}} 0.6 \mathrm{mmol}$ LDA was used. ${ }^{b}$ Product of desilylation. 
Next, the scope for another skeletal reorganization toward propargyl sulfonamide was also investigated. As shown in Fig. 5, a variety of ynamides were treated with LDA and DMPU toward the formation of propargyl sulfonamides, and the amino substitutions like $n$-butyl, cyclopentanyl, thiophene3-ethyl, and protected alcohol, were compatible with this process (3b-3e). With respect to the sulfonyl substitutions, the cyclopentanyl and cyclohexanyl were applicable in the process to deliver the corresponding products in good yields (3f-3i). Meanwhile, alkynes with substitution on the aryl ring, including 2-fluoro, 2-chloro, 3-methyl, 4-methyl, 4-pentyl, and 4-fluoro, could well engage in this skeletal

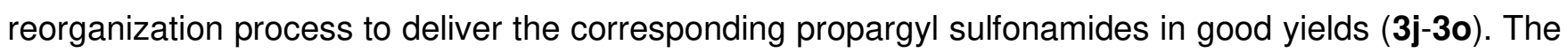
naphthyl and pyridinyl groups were also applicable to deliver the products smoothly (3p-3q). This skeletal reorganization involves an interesting 1,3 -alkyne migration from $\mathrm{N}$-atom to $\mathrm{C}$-atom. Propargyl sulfonamide is a versatile synthon and their synthesis is challenging by conventional methods. Thus, this protocol provides a simple and efficient method to these molecules from readily available materials along with the fascinating process. 

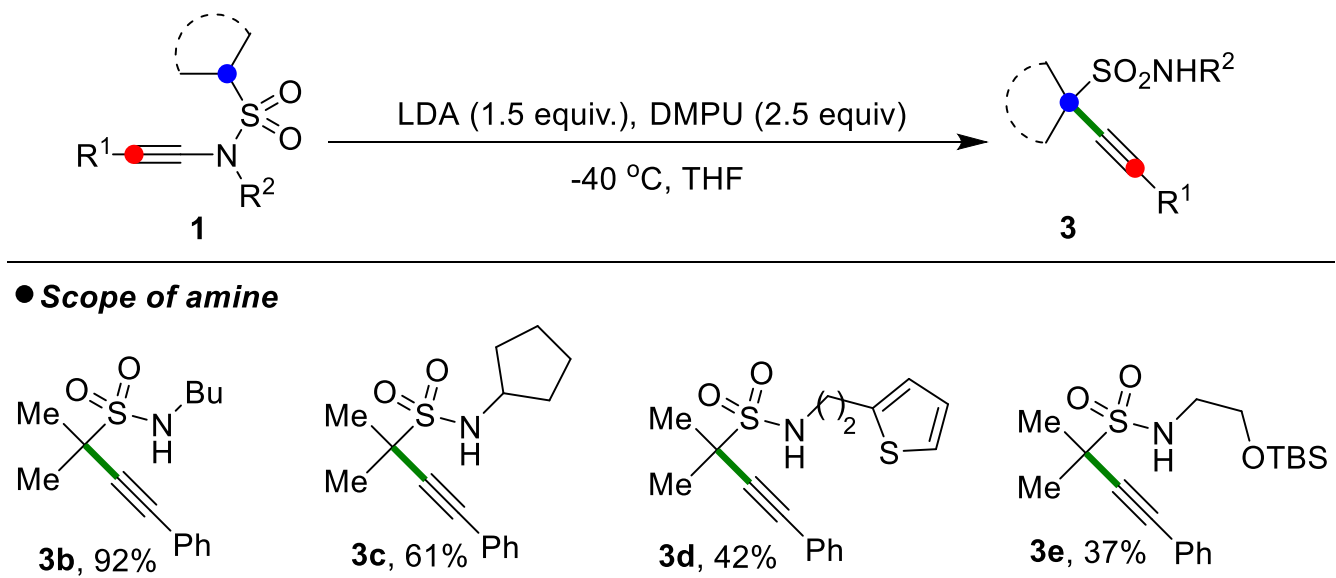

- Scope of sulfonyl
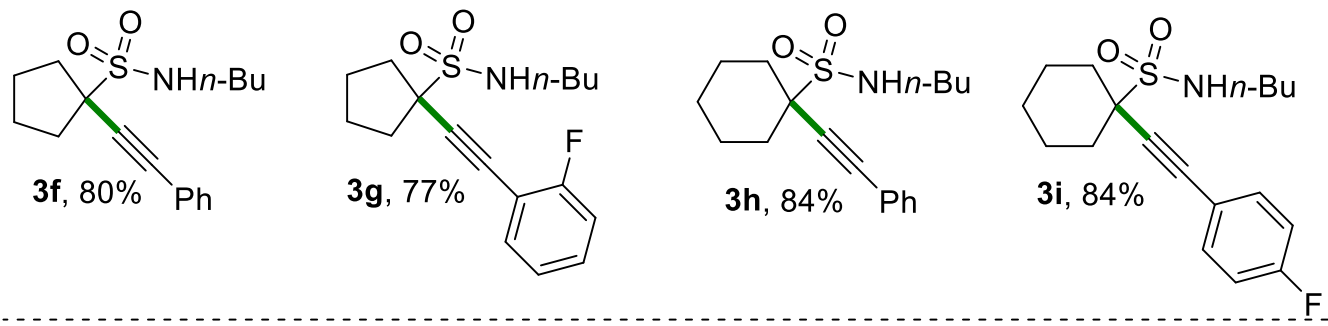

- Scope of alkyne

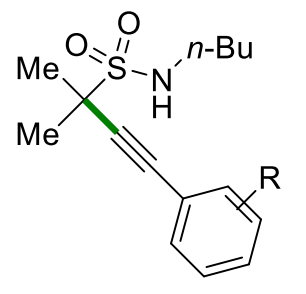

$3 \mathbf{j}, \mathrm{R}=2-\mathrm{F}, 70 \%$

3k, $\mathrm{R}=2-\mathrm{Cl}, 73 \%$

$3 \mathrm{l}, \mathrm{R}=3-\mathrm{Me}, 66 \%$

$3 \mathrm{~m}, \mathrm{R}=4-\mathrm{Me}, 64 \%$

3n, $R=4$-pentyl, $81 \%$

3o, $R=4-F, 68 \%$
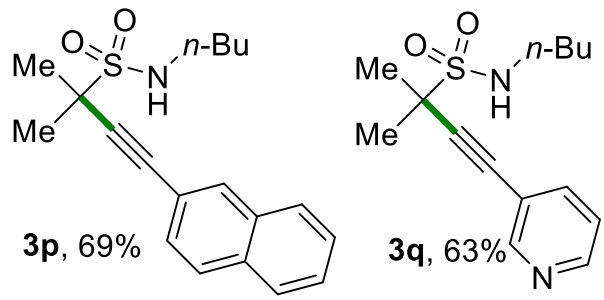

Fig. 5. Scope of propargyl sulfonamides. Standard condition: $1(0.2 \mathrm{mmol})$, LDA (0.3 mmol), DMPU (0.5 $\mathrm{mmol})$, THF $(2 \mathrm{~mL}),-40^{\circ} \mathrm{C}, 1 \mathrm{hr}$, then treated with $\mathrm{MeOH}(0.1 \mathrm{~mL})$. Yields refer to isolated products.

Synthetic applications and mechanism study. To demonstrate the synthetic utility of this skeletal reorganization, an $8 \mathrm{mmol}$ scale reaction was conducted (Fig. 6a). Under the standard reaction conditions, $1 \mathbf{a}$ could be selectively transformed to $\mathbf{2} \mathbf{a}$ and $\mathbf{3 a}$ in gram-scale, indicating that these skeletal reorganization processes were practical. Considering that these processes may involve lithium intermediates which could offer opportunities for divergent functionalization of products, the derivatization was carried out. For example, when ynamide 1 were treated with LDA, various electrophilic reagents instead of $\mathrm{MeOH}$ were used to quench the reaction, and those electrophilic groups such as 
methyl, allyl, propargyl, protected ethanol-2-yl, acetate and acetyl, were found placed on the amino group (Fig. 6b). This result not only indicated that a lithium amino intermediate is involved in the reorganization process, but also offered a vast potential for further derivatization of thiete sulfone skeletons. Similarly, when the LDA/DMPU mediated skeletal reorganization process of ynamide 1a was quenched with Mel, a $\mathrm{N}$-methyl propargyl sulfonamide product $\mathbf{5}$ was obtained in good yield (Fig. 6c). This experiment suggested the existence of sulfonamide anion intermediate after this skeletal reorganization process.

a) Gram-scale experiments

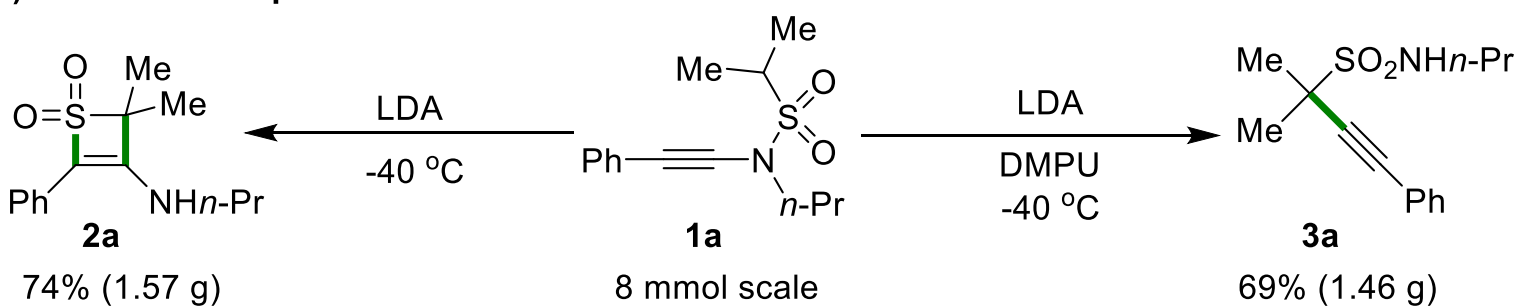

b) Electrophilic reagents-quenched reorganization toward $\boldsymbol{N}$-functionalized thiete sulfones

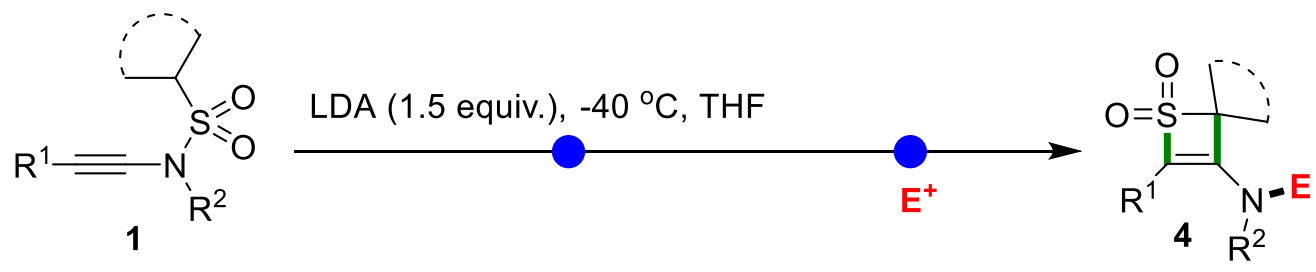

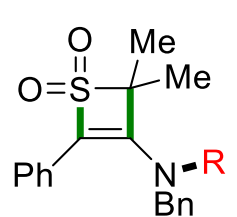

4a, $R=M e, 71 \%$

4b, $\mathrm{R}=$ allyl, $58 \%$

4c, $\mathrm{R}=$ propargyl, $55 \%$

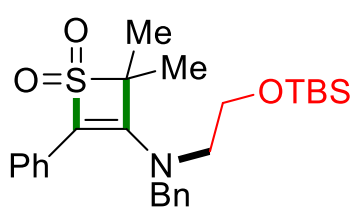

4d, $60 \%$

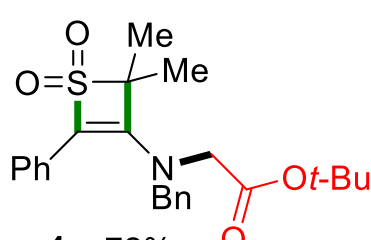

4 e, $72 \%$<smiles>CC1(C)C(NC(=O)c2ccccc2)=C(c2ccccc2)S1(=O)=O</smiles>

4f, $56 \%$

c) Mel-quenched reorganization toward $\mathbf{N}$-methyl propargyl sulfonamide

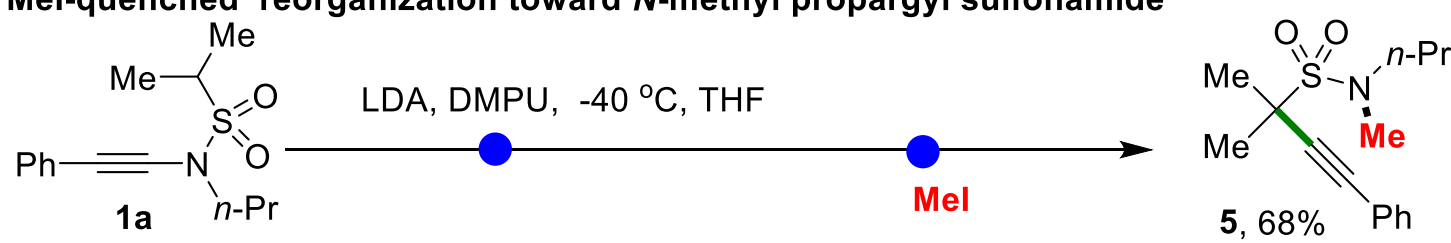

Fig. 6. Synthetic applications. a. Gram-scale reaction. b. Electrophilic reagents-quenched reorganization toward $\mathrm{N}$-functionalized thiete sulfones, for details of electronic reagents, see Supplementary. c. Melquenched reorganization toward $\mathrm{N}$-methyl propargyl sulfonamide. 
In order to view more insights into the reaction, the mechanism exploration was conducted. For example, the crossover reaction was carried out to test whether any intramolecular group exchange was involved in the process. As shown in Fig. 7a, when ynamide 1 $\mathrm{r}$ and $\mathbf{1 x}$ were subjected in one-pot under the standard reaction condition, $\mathbf{2 q}$ and $\mathbf{2 v}$ were exclusively formed in $79 \%$ and $73 \%$ yields respectively, and this excluded the possibility of intermolecular group exchange. Besides, treating $N$-acetyl ynamide 10' with LDA at $0{ }^{\circ} \mathrm{C}$ for 1 hour and then quenching the reaction with water could exclusively deliver a TIPS-tethered acetyl amide compound 6 in 59\% yield (Fig. 7b). We assumed that the in situ generated lithium enolate $\mathbf{B}$ might undergo an anionic 4-exo-dig cyclization to deliver intermediate $\mathbf{C}$, and the workup of water would lead to protonation and the following hydrolysis of methylene-1,3-oxazetidine would finally give the amide product $\mathbf{6}$. This outcome indicated that anionic 4-exo-dig cyclization is more favored than 5-endo-dig cyclization in similar processes of ynamides.

a) Crossover experiment

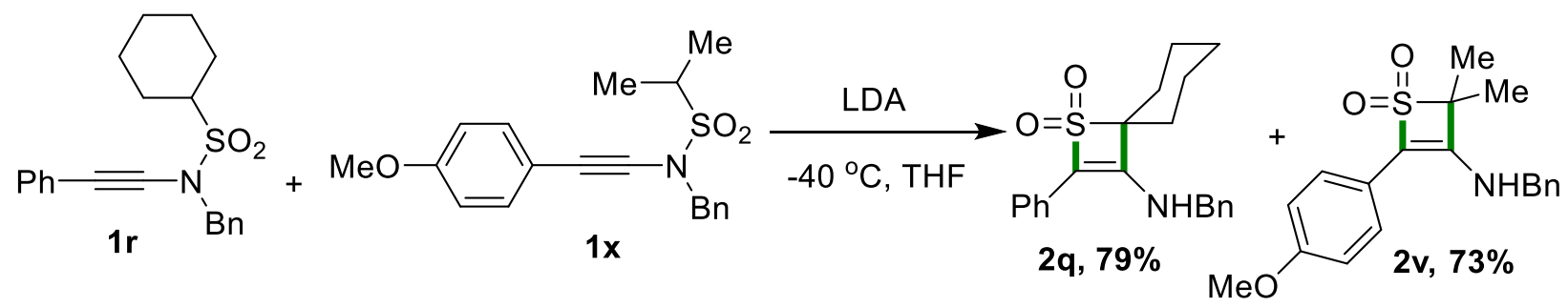

b) Reaction of $\boldsymbol{N}$-acetyl ynamide<smiles>CC(=O)N(C#CSP(=O)(O)c1ccccc1)Nc1ccccc1</smiles>

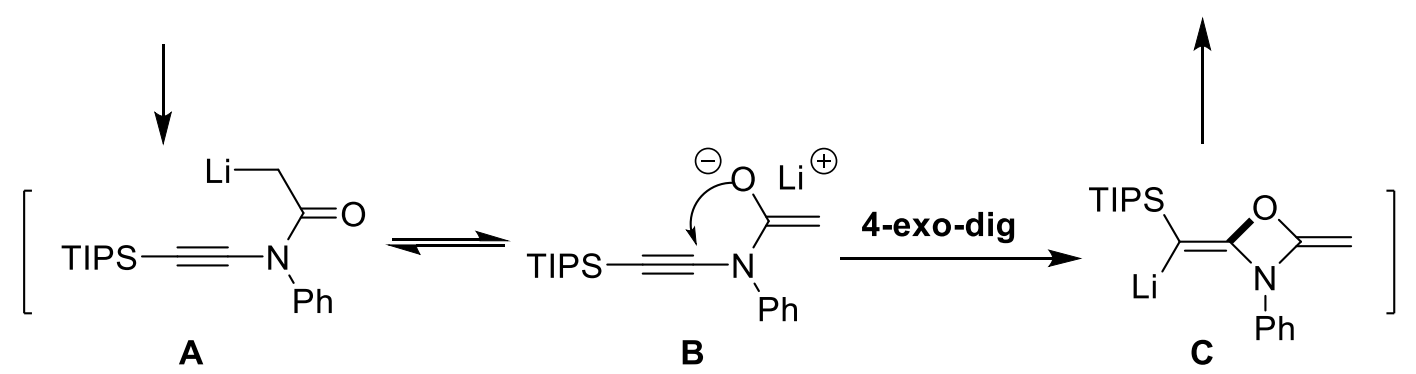

Fig. 7. Mechanistic experiments. a. Crossover reaction. b. Reaction of $\mathrm{N}$-acetyl ynamide. 
Based on these results, a plausible reaction mechanism for this skeletal reorganization divergence is proposed (Fig. 8). Initially, the a-position of sulfonyl group would undergo lithiation upon treatment with LDA to deliver $\mathbf{A}$, and then a 4-exo-dig cyclization would occur to generate four-membered $\beta$-sultam intermediate $\mathbf{B}^{63-64,67-68}$. At this stage, $\mathbf{B}$ shows a ligand-dependent divergent reactivity: (1) In the absence of ligands, intermediate B presumably undergoes a 1,3-sulfonyl migration to form lithium thiete sulfone intermediate $\mathbf{C}^{69-70}$, which could be protonated by $\mathrm{MeOH}$ to deliver product $\mathbf{2}$. When $\mathrm{MeOH}$ was replaced by other electrophilic reagents, intermediate $\mathbf{C}$ could be functionalized directly to obtain $\mathrm{N}$-substituted thiete sulfone products. (2) In the presence of DMPU, intermediate B might coordinate with DMPU to form D. Subsequently, intermediate $\mathbf{D}$ may undergo a $\beta$-elimination to generate lithium propargyl sulfonamide $\mathbf{E}$, and the following protonation would furnish product 3 . In terms of the structure of compounds 3, this skeletal reorganization process can be regarded as a 1,3-alkyne migration.

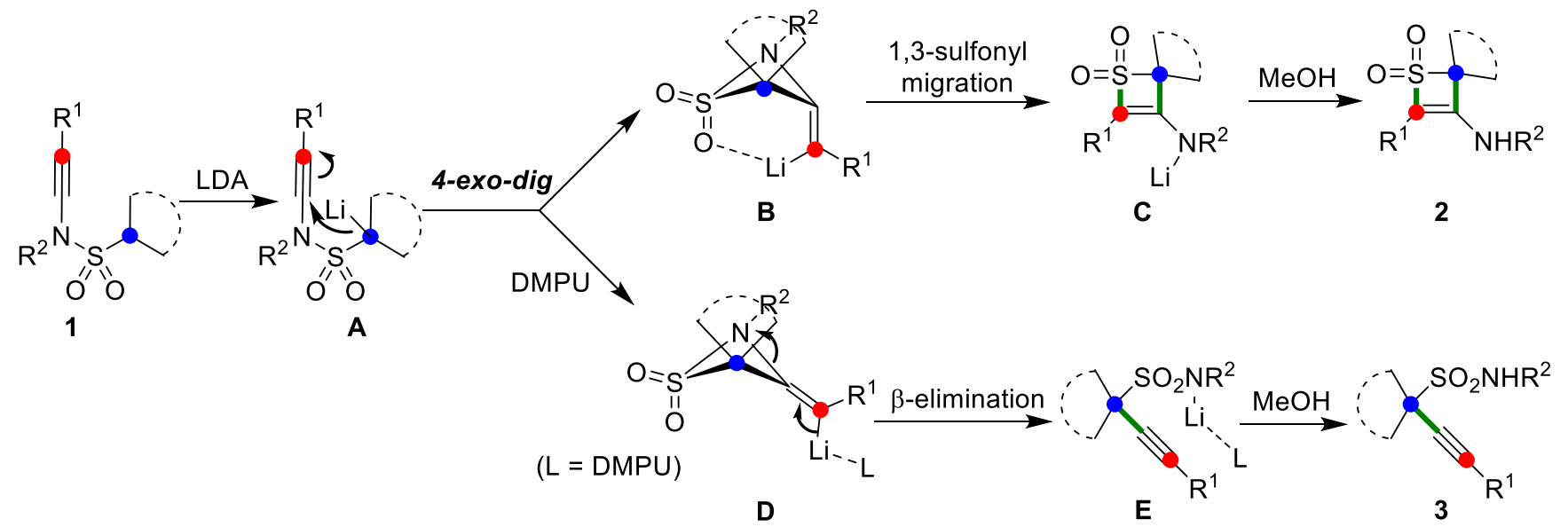

Fig. 8. Plausible mechanism.

\section{Discussion}

In summary, we have discovered an unprecedented skeletal reorganization divergence of $\mathrm{N}$-sulfonyl ynamides. Upon treatment with lithium base, the $\mathrm{N}$-sulfonyl ynamides would undergo lithiation/cyclization and the sequential ligand-determining 1,3-sulfony migration or $\beta$-elimination. Therefore, this protocol not 
only represents a new skeletal reorganization mode, but also provides facile and selective access to privileged molecules from the easily accessible ynamides.

\section{Methods}

General procedure for the synthesis of thiete sulfones 2. An oven-dried schlenk tube equipped with a magnetic stirrer bar was purged with argon three times. Ynamide $1(0.2 \mathrm{mmol})$ was dissolved in $2 \mathrm{~mL}$ anhydrous THF and added by a syringe. The mixture was cooled to $-40^{\circ} \mathrm{C}$ and LDA $(2 \mathrm{~mol} / \mathrm{L}$ in THF, $0.15 \mathrm{~mL}, 0.3 \mathrm{mmol})$ was added dropwise. The reaction was stirred at $-40^{\circ} \mathrm{C}$ for another $1 \mathrm{~h} . \mathrm{MeOH}(0.1$ $\mathrm{mL}$ ) was added to quench the reaction and then the mixture was concentrated under vacuum to obtain the residue, which was further purified by silica gel column chromatography using ethyl acetate/petroleum ether as eluent to give thiete sulfones 2.

General procedure for the synthesis of propargyl sulphonamides 3. An oven-dried schlenk tube equipped with a magnetic stirrer bar was purged with argon three times. Ynamide 1 (0.2 mmol) was dissolved in $2 \mathrm{~mL}$ anhydrous THF and added by a syringe. DMPU (62 $\mu \mathrm{L}, 0.5 \mathrm{mmol})$ was added and the mixture was cooled to $-40^{\circ} \mathrm{C}$. Subsequently, LDA (2 mol/L in THF, $0.15 \mathrm{~mL}, 0.3 \mathrm{mmol}$ ) was added dropwise. The reaction was stirred at $-40{ }^{\circ} \mathrm{C}$ for another $1 \mathrm{~h}$, and then $\mathrm{MeOH}(0.1 \mathrm{~mL})$ was added to quench the reaction. The mixture was concentrated under vacuum to obtain the residue, which was further purified by silica gel column chromatography using ethyl acetate/petroleum ether as eluent to give propargyl sulphonamides 3 .

\section{Data availability}

Data for the crystal structures reported in this paper have been deposited at the Cambridge Crystallographic Data Center (CCDC) under the deposition numbers CCDC: 1999861 (2a), 1999862 (2b), 1999863 (2j), 1999864 (2k), 1999865 (2q), 1999866 (2a'). Copies of these data can be obtained 
free of charge via www.ccdc.cam.ac.uk/data_request/cif. All other data supporting the findings of this study, including experimental procedures and compound characterization, are available within the paper and its Supplementary Information files, or from the corresponding authors on request.

\section{Acknowledgement}

We are grateful for the financial support by the National Natural Science Foundation of China (21971222), Leading Talent of "Ten Tousand Plan"-National High-Level Talents Special Support Plan. We thank Jianyang Pan (Research and Service Center, College of Pharmaceutical Sciences, Zhejiang University) for performing NMR spectrometry for structure elucidation

\section{Author contributions}

L. Zeng, Y. Lin and J. Li performed experiments. S. Cui conceived and directed the project and wrote the paper. All authors discussed the results and commented on the manuscript.

\section{References}

1. Nakamura, I. \& Tanaka, K. Skeletal rearrangement reactions: in transition-metal-mediated aromatic ring construction, Wiley, Hoboken, 2013, pp. $743-771$.

2. Xie, X. N. \& Zu, L. S. Skeletal rearrangements as strategies for the total Syntheses of indole alkaloids. Synlett 29, 1008-1013 (2018).

3. Aubert, C., Buisine, O. \& Malacria, M. The behavior of 1,n-enynes in the presence of transition metals. Chem. Rev. 102, 813-834 (2002).

4. Zhang, L. M., Sun, J. W. \& Kozmin, S. A. Gold and platinum catalysis of enyne cycloisomerization. Adv. Synth. Catal. 348, 2271-2296 (2006).

5. Tobisu, M. \& Chatani, N. Catalytic reactions involving the cleavage of carbon-cyano and carbon-carbon triple bonds. Chem. Soc. Rev. 37, 300-307 (2008).

6. Chatani, N., Inoue, H., Kotsuma, T. \& Murai, S. Skeletal reorganization of enynes to 1-vinylcycloalkenes catalyzed by $\mathrm{GaCl}_{3}$. J. Am. Chem. Soc. 124, 10294-10295 (2002).

7. Mamane, V., Gress, T., Krause, H. \& Furstner, A. Platinum- and gold-catalyzed cycloisomerization reactions of hydroxylated enynes. J. Am. Chem. Soc. 126, 8654-8655 (2004).

8. Tang, J.-M., Bhunia, S., Sohel, S. M. A., Lin, M.-Y., Liao, H.-Y., Datta, S., Das, A. \& Liu, R.-S. The skeletal rearrangement of gold- and platinum-catalyzed cycloisomerization of cis-4,6-dien-1-yn-3-ols: Pinacol rearrangement and formation of bicyclo[4.1.0]heptenone and reorganized styrene derivatives. J. Am. Chem. Soc. 129, 15677-15683 (2007).

9. Ota, K., Lee, S. I., Tang, J.-M., Takachi, M., Nakai, H., Morimoto, T., Sakurai, H., Kataoka, K. \& Chatani, N. $\mathrm{Rh}$ (II)-Catalyzed skeletal reorganization of 1,6-and 1,7-enynes through electrophilic activation of alkynes. J. Am. Chem. Soc. 131, 15203-15211 (2009). 
10. Nakamura, I., Zhang, D. \& Terada, M. Copper-Catalyzed Tandem [2,3]-rearrangement and 6ா-3-azatriene electrocyclization in (E)-o-propargylic $\alpha, \beta$-unsaturated oximes. J. Am. Chem. Soc. 132, 7884-7886 (2010).

11. Wang, G., Huang, H., Guo, W., Qian, C. \& Sun, J. Unusual skeletal reorganization of oxetanes for the synthesis of 1,2-dihydroquinolines. Angew. Chem., Int. Ed. 59, 10.1002/anie.201916727, (2020).

12. L. Li, Z.-L. Li, Q.-S. Gu, N. Wang, X.-Y. Liu, A remote C-C bond cleavage-enabled skeletal reorganization: Access to medium-/large-sized cyclic alkenes. Sci. Adv. 3, e1701487 (2017).

13. Zhang, L., Cao, T., Jiang, H. \& Zhu, S. Deconstructive reorganization: de novo synthesis of hydroxylated benzofuran. Angew. Chem., Int. Ed. 59, 4670-4677 (2020).

14. Volkova, K. D., Kovalska, V. B., Balanda, A. O., Vermeij, R. J., Subramaniam, V., Slominskii, Y. L. \& Yarmoluk, S. M. Cyanine dye-protein interactions: looking for fluorescent probes for amyloid structures. J. Biochem. Bioph. Meth. 70, 727-733 (2007).

15. Merckle, L., Dubois, J., Place, E., Thoret, S., Gueritte, F., Guenard, D., Poupat, C., Ahond, A. \& Potier, P. Semisynthesis of D-ring modified taxoids: Novel thia derivatives of docetaxel. J. Org. Chem. 66, 5058-5065 (2001).

16. Shabalina, Y. V., Khaliullin, F. A., Nikitina, I. L., Miftakhova, A. F. \& Sharafutdinov, R. M. Synthesis and Antidepressant Activity of 8-amino-substituted 1-butyl-3-methylxanthines containing a thietane ring. Pharm. Chem. J. 53, 1009-1012 (2020).

17. Liu, C., Nan, Y. Y., Xia, Z. F., Gu, K. D., Chen, C., Dong, X. C., Ju, D. W. \& Zhao, W. L. Discovery of novel hydroxyamidine derivatives as indoleamine 2,3-dioxygenase 1 inhibitors with in vivo anti-tumor efficacy. Bioorg. Med. Chem. Lett. 10.1016/j.bmcl.2020.127038.

18. Klen, E. E., Nikitina, I. L., Makarova, N. N., Miftakhova, A. F., Ivanova, O. A., Khaliullin, F. A. \& Alekhin, E. K. 3-Substituted thietane-1,1-dioxides: synthesis, antidepressant activity, and in silico prediction of their pharmacokinetic and toxicological properties. Pharm. Chem. J. 50, 642-648 (2017).

19. Renold, P., Zambach, W., Maienfisch, P. \& Muehlebach, M. Insecticidal compounds. PCT Int. Appl. WO2009080250.

20. Paquette, L. A. Fused aromatic derivatives of thiete and thiete sulfone. J. Org. Chem. 30, 629-633 (1965).

21. Dittmer, D. C. \& Takashina, N. Synthesis and properties of a naphthothiete sulfone (3,8-diphenyl-2hnaphth[2,3-b]thiete-1,1-dioxide). Tetrahedron Lett. 3809-3813 (1964).

22. Dittmer, D. C., Takashin.N, Balquist, J. M. \& Ikura, K. Derivatives of thiacyclobutene (thiete) .5. molecular reorganization in reaction of thiete sulfone and tetraphenylcyclopentadienone. J. Org. Chem. 37, 225-230 (1972).

23. Dittmer, D. C. \& Glassman, R. Diazo alkane adducts of thiete sulfone (thiacyclobutene 1,1-dioxide) in synthesis of thiabicyclopentane dioxides, pyrazoles, and tetrahydrothiophene sulfones. J. Org. Chem. 35, 999-1004 (1970).

24. Baumann, A. N., Reiners, F., Juli, T. \& Didier, D. Chemodivergent and stereoselective access to fused isoxazoline azetidines and thietanes through [3+2]-cycloadditions. Org. Lett. 20, 6736-6740 (2018).

25. Eisold, M., Miiller-Deku, A., Reiners, F. \& Didier, D. parallel approaches for the functionalization of thietes: alpha-metalation versus C-H activation. Org. Lett. 20, 4654-4658 (2018).

26. Baumann, A. N., Reiners, F., Siegle, A. F., Mayer, P., Trapp, O. \& Didier, D. Thiete dioxides as templates towards novel twisted scaffolds and macrocyclic structures. Chem. Eur. J. 10.1002/chem.201905751.

27. Dittmer, D. C. \& Christy, M. E. Thiete sulfone. J. Org. Chem. 26, 1324-1326 (1961).

28. Dittmer, D. C. \& Christy, M. E. Derivatives of thiacyclobutene (thiete) and thiacyclobutane (thietane) .1. reactions of thiete sulfone. J. Am. Chem. Soc. 84, 399-402 (1962).

29. Dittmer, D. C. \& Balquist, J. M. Derivatives of thiacyclobutenes (thietes) .III. synthesis of highly unsaturated thiete sulfones. J. Org. Chem. 33, 1364-1365 (1968). 
30. Lancaster, M. \& Smith, D. J. H. Efficient syntheses of thietanes and thiete 1,1-dioxide using phase-transfer catalysis. Synthesis 582-583 (1982).

31. Chang, P. L. F. \& Dittmer, D. C. Use of $\mathrm{N}, \mathrm{N}$-dimethylvinylamine in an improved synthesis of derivatives of thietane and thiete. J. Org. Chem. 34, 2791-2792 (1969).

32. Block, E. Product Subclass 12: Thietes and Derivatives. Science of Synthesis 33, 187-202 (2007).

33. Dodd, R. H. \& Cariou, K. Ketenimines generated from ynamides: versatile building blocks for nitrogencontaining scaffolds. Chem.- Eur. J. 24, 2297-2304 (2018).

34. Evano, G., Michelet, B. \& Zhang, C. The anionic chemistry of ynamides: a review. C. R. Chim. 20, 648-664 (2017).

35. Prabagar, B., Ghosh, N. \& Sahoo, A. K. Cyclization and cycloisomerization of $\pi$-tethered ynamides: an expedient synthetic method to construct carbo- and heterocycles. Synlett 28, 2539-2555 (2017).

36. Li, L., Tan, T.-D., Zhang, Y.-Q., Liu, X. \& Ye, L.-W. Recent advances in transition-metal-catalyzed reactions of alkynes with isoxazoles. Org. Biomol. Chem. 15, 8483-8492 (2017).

37. Pan, F., Shu, C. \& Ye, L.-W. Recent progress towards gold-catalyzed synthesis of $\mathrm{N}$-containing tricyclic compounds based on ynamides. Org. Biomol. Chem. 14, 9456-9465 (2016).

38. Evano, G., Theunissen, C. \& Lecomte, M. Ynamides: powerful and versatile reagents for chemical synthesis. Aldrichimica Acta 48, 59-70 (2015).

39. Wang, X.-N., Yeom, H.-S., Fang, L.-C., He, S., Ma, Z.-X., Kedrowski, B. L. \& Hsung, R. P. Ynamides in ring forming transformations. Acc. Chem. Res. 47, 560-578 (2014).

40. DeKorver, K. A., Li, H., Lohse, A. G., Hayashi, R., Lu, Z., Zhang, Y. \& Hsung, R. P. Ynamides: a modern functional group for the new millennium. Chem. Rev. 110, 5064-5106 (2010).

41. Evano, G., Coste, A. \& Jouvin, K. Ynamides: versatile tools in organic synthesis. Angew. Chem., Int. Ed. 49, 2840-2859 (2010).

42. Zhou, B., Tan, T.-D., Zhu, X.-Q., Shang, M.-Z. \& Ye, L.-W. Reversal of regioselectivity in ynamide chemistry. Acs Catal. 9, 6393-6406 (2019).

43. Lecomte, M. \& Evano, G. Harnessing the electrophilicity of keteniminium ions: a simple and straightforward entry to tetrahydropyridines and piperidines from ynamides. Angew. Chem., Int. Ed. 55, 4547-4551 (2016).

44. Schotes, C. \& Mezzetti, A. Enantioselective ficini reaction: ruthenium/pnnp-catalyzed [2+2] cycloaddition of ynamides with cyclic enones. Angew. Chem., Int. Ed. 50, 3072-3074 (2011).

45. Zeng, Z., Jin, H., Rudolph, M., Rominger, F. \& Hashmi, A. S. K. Gold(III)-catalyzed site-selective and divergent synthesis of 2-aminopyrroles and quinoline-based polyazaheterocycles. Angew. Chem., Int. Ed. 57, 16549-16553 (2018).

46. Al-Rashid, Z. F. \& Hsung, R. P. Reactive intermediates from DMDO oxidation of ynamides. Trapping of a de novo chiral push-pull carbene via cyclopropanation. Org. Lett. 10, 661-663 (2008).

47. Couty, S., Meyer, C. \& Cossy, J. Chemoselective epoxidation of ene-ynamides: Intramolecular cyclopropanation induced by the intermediate alpha-oxocarbene. Synlett, 2819-2822 (2007).

48. Liu, R. H., Winston-McPherson, G. N., Yang, Z. Y., Zhou, X., Song, W. Z., Guzei, I. A., Xu, X. F. \& Tang, W. P. Generation of rhodium(I) carbenes from ynamides and their reactions with alkynes and alkenes. J. Am. Chem. Soc. 135, 8201-8204 (2013).

49. Shu, C., Wang, Y.-H., Zhou, B., Li, X.-L., Ping, Y.-F., Lu, X. \& Ye, L.-W. Generation of alpha-Imin gold carbenes through gold-catalyzed intermolecular reaction of azides with ynamides. J. Am. Chem. Soc. 137, 9567-9570 (2015).

50. Gourdet, B. \& Lam, H. W. Stereoselective synthesis of multisubstituted enamides via rhodium-catalyzed carbozincation of ynamides. J. Am. Chem. Soc. 131, 3802-3803 (2009).

51. Zeng, X., Li, J., Ng, C. K., Hammond, G. B. \& Xu, B. (Radio)fluoroclick reaction enabled by a hydrogen- 
bonding cluster. Angew. Chem., Int. Ed. 57, 2924-2928 (2018).

52. Hu, L., Xu, S., Zhao, Z., Yang, Y., Peng, Z., Yang, M., Wang, C. \& Zhao, J. Ynamides as racemization-free coupling reagents for amide and peptide synthesis. J. Am. Chem. Soc. 138, 13135-13138 (2016).

53. Yang, J., Wang, C., Xu, S. \& Zhao, J. Ynamide-mediated thiopeptide synthesis. Angew. Chem., Int. Ed. 58, 1382-1386 (2019).

54. Yang, M., Wang, X. \& Zhao, J. Ynamide-mediated macrolactonization. Acs Catal. 10, 5230-5235 (2020).

55. Huang, B., Zeng, L., Shen, Y. \& Cui, S. One-pot multicomponent synthesis of $\beta$-amino amides. Angew. Chem., Int. Ed. 56, 4565-4568 (2017).

56. Shen, Y., Huang, B., Zeng, L. \& Cui, S. Single Reactant Replacement Approach of Passerini Reaction: One-Pot Synthesis of $\beta$-Acyloxyamides and Phthalides. Org. Lett. 19, 4616-4619 (2017).

57. Chen, R., Liu, Y. \& Cui, S. 1,4-Conjugate addition/esterification of ortho-quinone methides in a multicomponent reaction. Chem. Commun. 54, 11753-11756 (2018).

58. Hashmi, A. S. K., Salathé, R. \& Frey, W. Gold-catalyzed cyclization of N-alkynyl carbamates. Synlett, 1763-1766 (2007).

59. Frischmuth, A. \& Knochel, P. Preparation of functionalized indoles and azaindoles by the intramolecular copper-mediated carbomagnesiation of ynamides. Angew. Chem., Int. Ed. 52,10084-10088 (2013).

60. Prabagar, B., Mallick, R. K., Prasad, R., Gandon, V. \& Sahoo, A. K. Umpolung reactivity of ynamides: an unconventional [1,3]-sulfonyl and [1,5]-sulfinyl migration cascade. Angew. Chem., Int. Ed. 58, 2365-2370 (2019).

61. Wang, Z.-S., Chen, Y.-B., Zhang, H.-W., Sun, Z., Zhu, C.-Y. \& Ye, L.-W. Ynamide smiles rearrangement triggered by visible-light-mediated regioselective ketyl-ynamide coupling: rapid access to functionalized indoles and isoquinolines. J. Am. Chem. Soc. 142, 3636-3644 (2020).

62. Gati, W., Rammah, M. M., Rammah, M. B., Couty, F. \& Evano, G. De novo synthesis of 1,4-dihydropyridines and pyridines. J. Am. Chem. Soc. 134, 9078-9081 (2012).

63. Gilmore, K., Mohamed, R. K. \& Alabugin, I. V. The Baldwin rules: revised and extended. Wires Comput. Mol.Sci. 6, 487-514 (2016).

64. Gilmore, K. \& Alabugin, I. V. Cyclizations of alkynes: revisiting baldwin's rules for ring closure. Chem Rev 111, 6513-6556 (2011).

65. Chen, R., Zeng, L., Huang, B., Shen, Y. \& Cui, S. Decarbonylative coupling of $\alpha$-keto acids and ynamides for synthesis of $\beta$-keto imides. Org. Lett. 20, 3377-3380 (2018).

66. Hasek, R. H., Meen, R. H. \& Martin, J. C. Reactions of alkanesulfonyl chlorides with ketene $\mathrm{N}, \mathrm{N}$ - and $\mathrm{O}, \mathrm{N}-$ acetals. J. Org. Chem. 30, 1495-1498 (1965).

67. Bailey, W. F. \& Aspris, P. H. Facile preparation of alkenylidenecycloalkanes by cyclization of acetylenic alkyllithiums bearing a propargylic leaving group. J. Org. Chem. 60, 754-757 (1995).

68. Bailey, W. F. \& Ovaska, T. V. Cyclization of acetylenic alkyllithiums. J. Am. Chem. Soc. 115, 3080-3090 (1993).

69. Flynn, A. J., Ford, A. \& Maguire, A. R. Synthetic and mechanistic aspects of sulfonyl migrations. Org. Biomol. Chem. 18, 2549-2610 (2020).

70. Teo, W. T., Rao, W. D., Koh, M. J. \& Chan, P. W. H. Gold-catalyzed domino aminocyclization/1,3-sulfonyl migration of $\mathrm{N}$-substituted $\mathrm{N}$-sulfonyl-aminobut-3-yn-2-ols to 1-substituted 3-sulfonyl-1H-pyrroles. J. Org. Chem. 78, 7508-7517 (2013). 
Figures

a) Skeletal reorganization

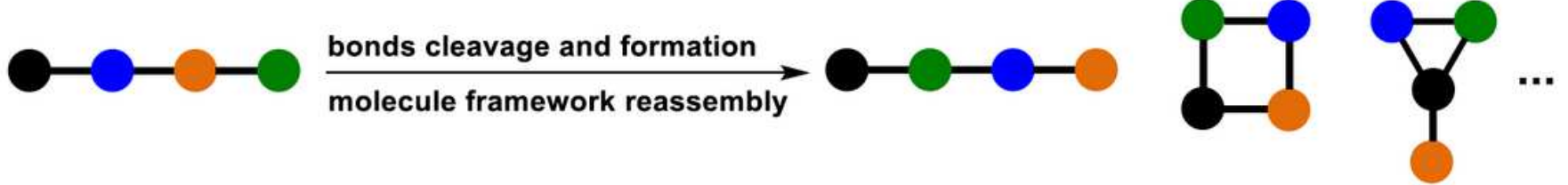

b) Sun's work

政 c) Liu's work

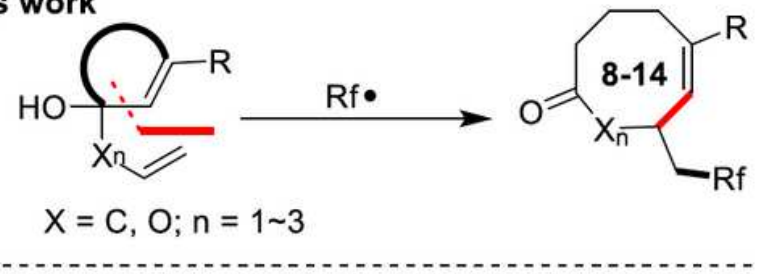

d) Zhu's work

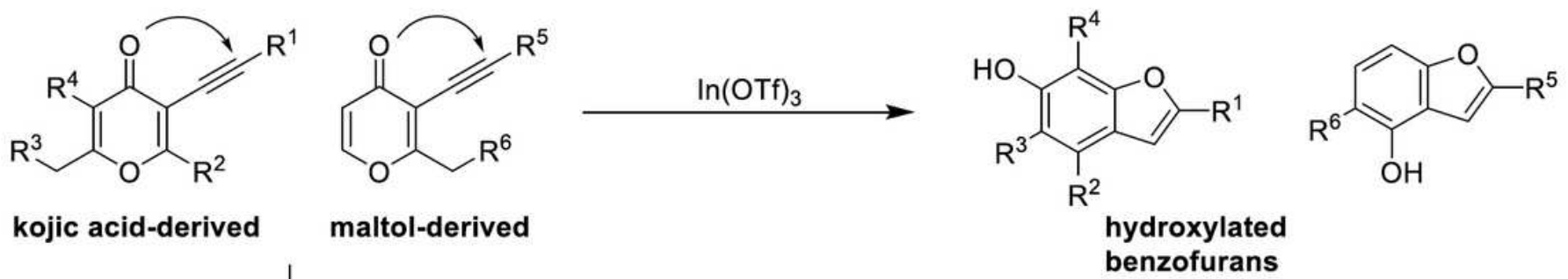

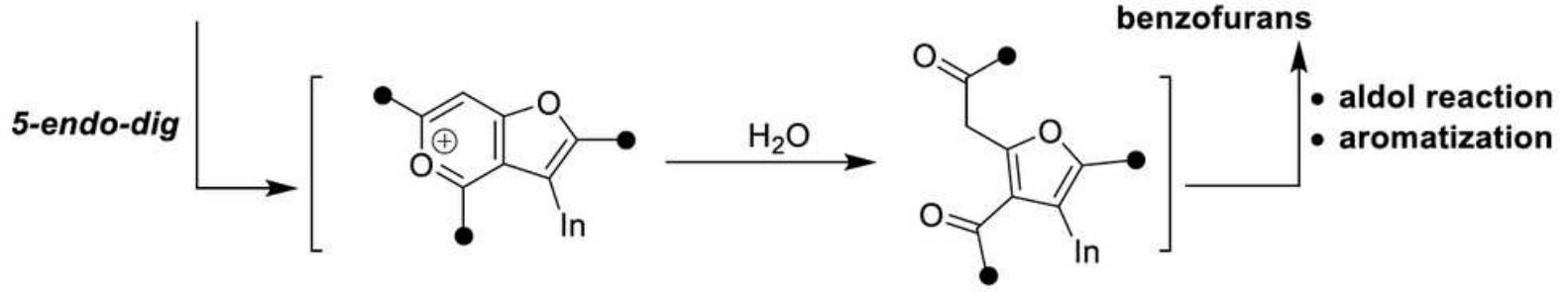

\section{Figure 1}

Skeletal reorganization. a Skeletal reorganization. b In-catalyzed skeletal reorganization of oxetanes. c Radical-initiated skeletal reorganization of olefines. $d$ In-catalyzed skeletal reorganization of kojic acid- or maltol-derived alkynes. 


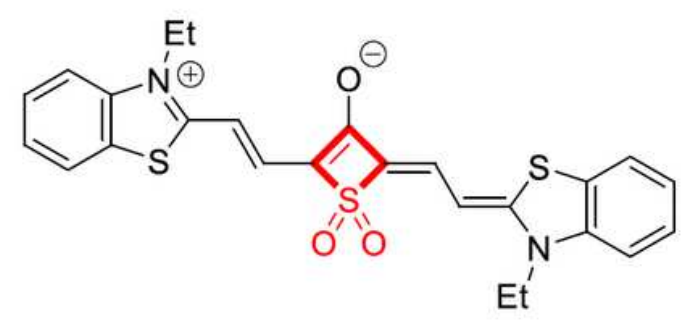

Cyanine dye

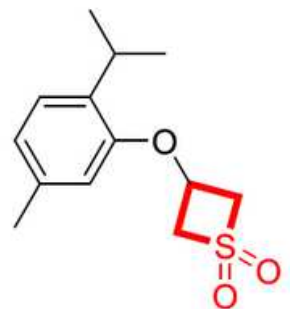

Antidepressant agent

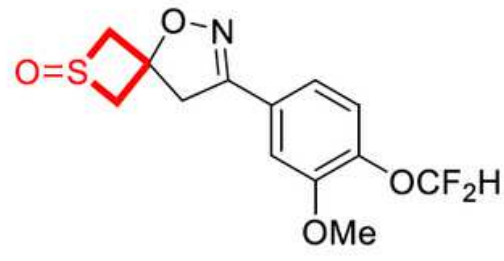

Phosphodiesterase inhibitor

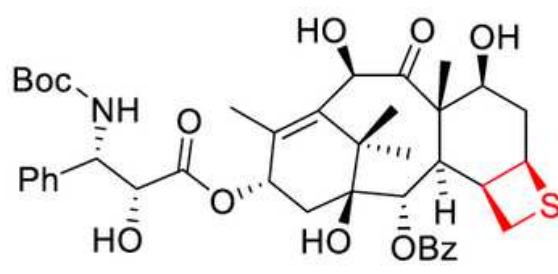

Taxol derivatives<smiles>Cc1cc(C2=NOC(c3cc(Cl)cc(Cl)c3)(C(F)(F)F)C2)ccc1C(=O)NC1CSC1</smiles>

Pesticide

\section{Figure 2}

Representative molecules containing the structures of sulfur-containing four-membered ring. 
a) Intramolecular cyclizations of ynamides

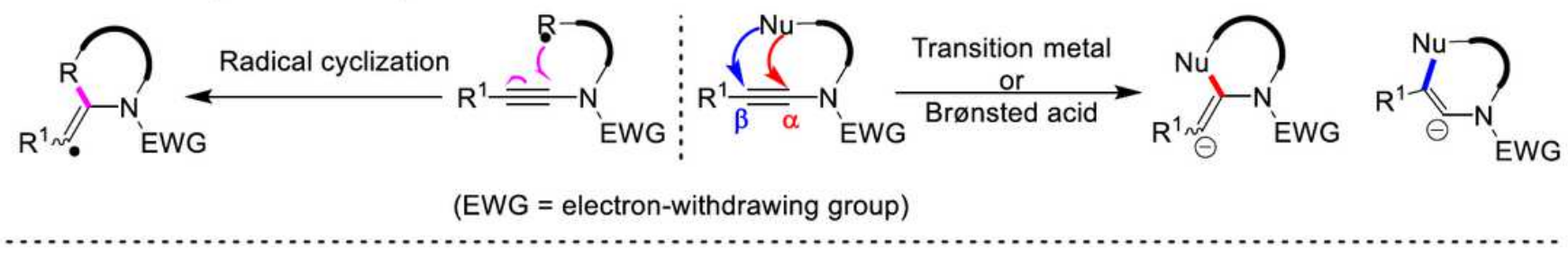

b) Evano's work: skeletal reorganization of $\mathrm{N}$-Boc ynamides

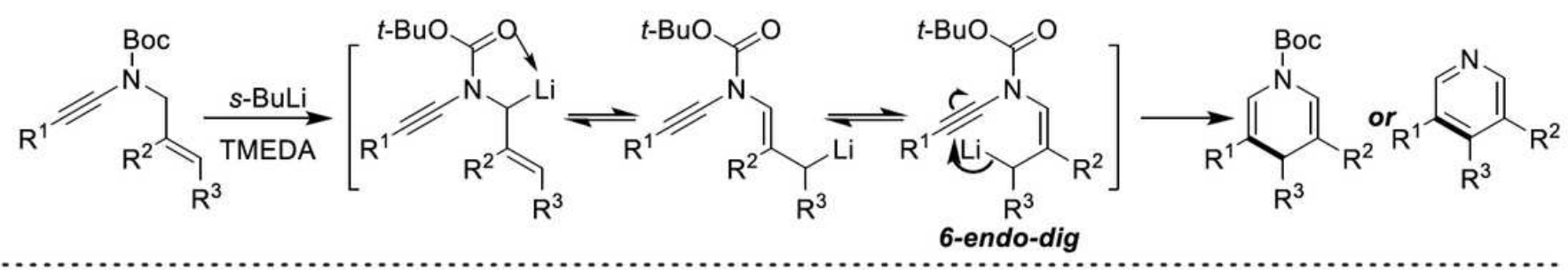

c) Our initial hypothesis

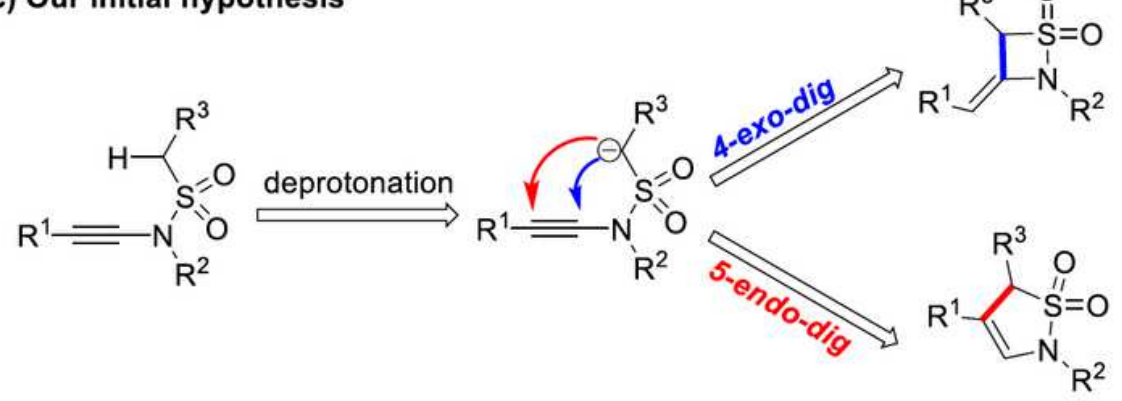

d) This work: skeletal reorganization divergence of $\mathrm{N}$-sulfonyl ynamides

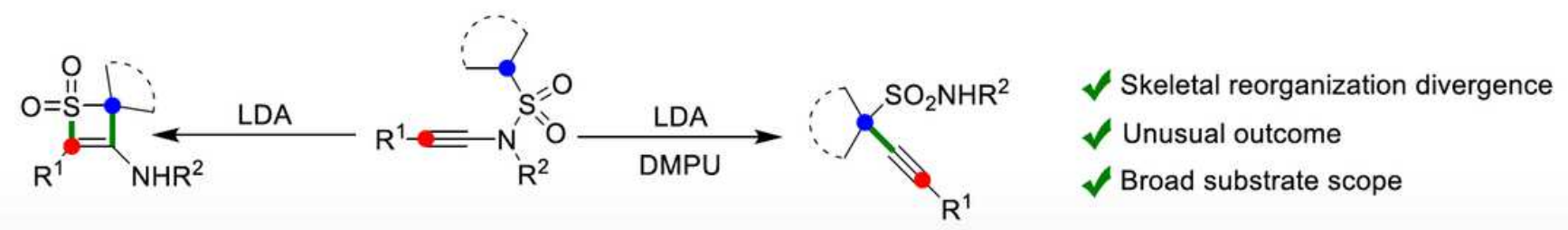

Figure 3

Skeletal reorganization of ynamides. a. Intramolecular cyclizations of ynamides. b. Skeletal reorganization of N-Boc ynamides. c. Initial hypothesis. d. Skeletal reorganization divergence of Nsulfonyl ynamides. 


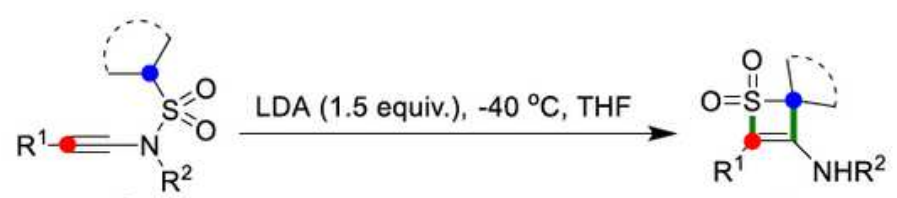

1

2

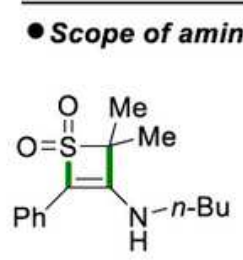

2b, $70 \%$

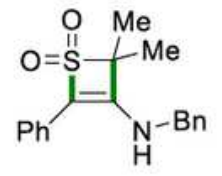

2c, $85 \%$

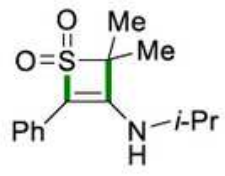

2d, $65 \%$

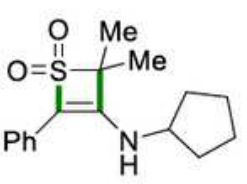

2e, $60 \%$

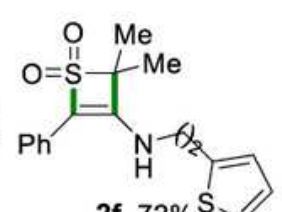

2f, $72 \% \mathrm{~S}$<smiles>CC(NC1=C(c2ccccc2)C(C)(C)C1(C)C)c1ccccc1</smiles>

2g, $56 \%$<smiles>C/C=C\CNC1=C(c2ccccc2)C(C)(C)S1(=O)=O</smiles>

2h, $78 \%$<smiles>CC1(C)C(NCCI)=C(c2ccccc2)S1(=O)=O</smiles>

2i, $81 \%$ OTBS

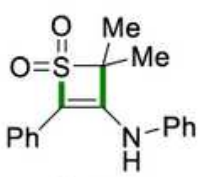

2j. $77 \%$

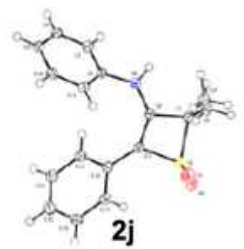

- Scope of sulfonyl<smiles>O=S1(=O)C=C(NC2=C(c3ccccc3)S(=O)(=O)C2)C1</smiles>

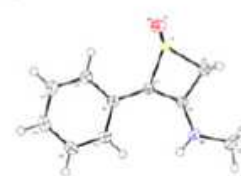<smiles>CCCCNC1=C(c2ccccc2)S(=O)(=O)C1</smiles><smiles>O=S1(=O)C(c2ccccc2)=C(NCc2ccccc2)C1c1ccccc1</smiles><smiles>CCCCNC1=C(c2ccccc2)C2(CCCC2)S1(=O)=O</smiles>

2k, $54 \%^{a}$

$2 k$

2I, $55 \%^{a}$

$2 \mathrm{~m}, 54 \%$

2n, $43 \%$<smiles>O=S1(=O)CC2(CCCC2)C(NCc2ccccc2)=C1c1ccccc1</smiles><smiles>CCCCNC1=C(c2ccccc2)C(CCCC)C1(CCC)[SH](=O)=O</smiles>

2 p, $43 \%$

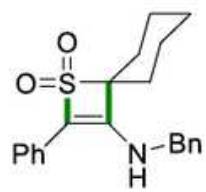

2q, $74 \%$

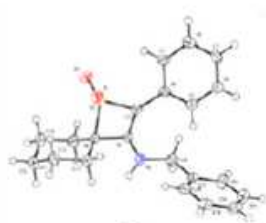

$2 q$

- Scope of alkyne<smiles>[R]c1ccccc1C1=C(NCc2ccccc2)C(C)(C)C1(C)C</smiles>

$2 r, R=2-\mathrm{Cl}, 67 \%$

2s, $\mathrm{R}=3-\mathrm{Me}, 74 \%$

2t, $R=4-M e, 63 \%$

2u, R $=4$-pentyl, $74 \%$

$2 v, R=4-O M e, 70 \%$

$2 \mathrm{w}, \mathrm{R}=4-\mathrm{F}, 78 \%$<smiles>CC1(C)C(NCc2ccccc2)=C(c2ccc3ccccc3c2)S(=O)(=O)C1(C)C</smiles><smiles>CC1(C)CS(=O)(=O)C(c2cccnc2)=C1NCc1ccccc1</smiles>

$2 \mathrm{x}, \mathrm{R}=4-\mathrm{Cl}, 85 \%$
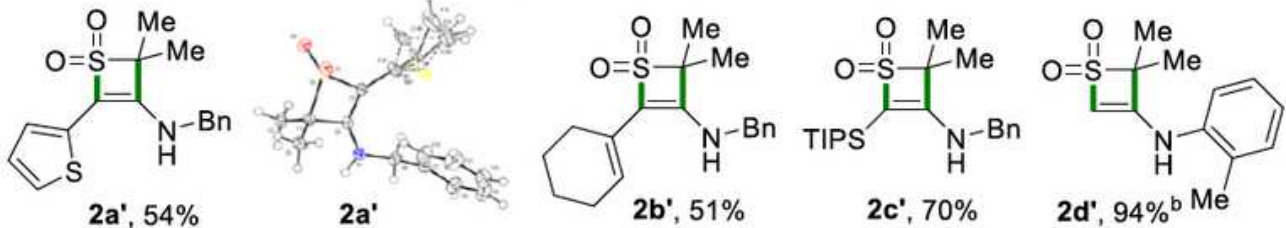

\section{Figure 4}

Scope of thiete sulfones. Standard condition: 1 ( $0.2 \mathrm{mmol}), \operatorname{LDA}(0.3 \mathrm{mmol})$, THF $(2 \mathrm{~mL}),-40 \mathrm{oC}, 1 \mathrm{hr}$, then treated with $\mathrm{MeOH}(0.1 \mathrm{~mL})$. Yields refer to isolated products. a0.6 mmol LDA was used. bProduct of desilylation. 


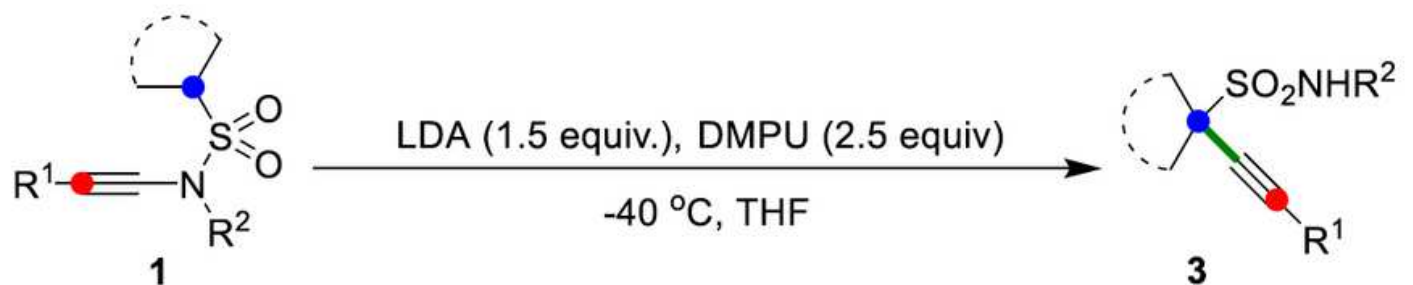

\section{- Scope of amine}

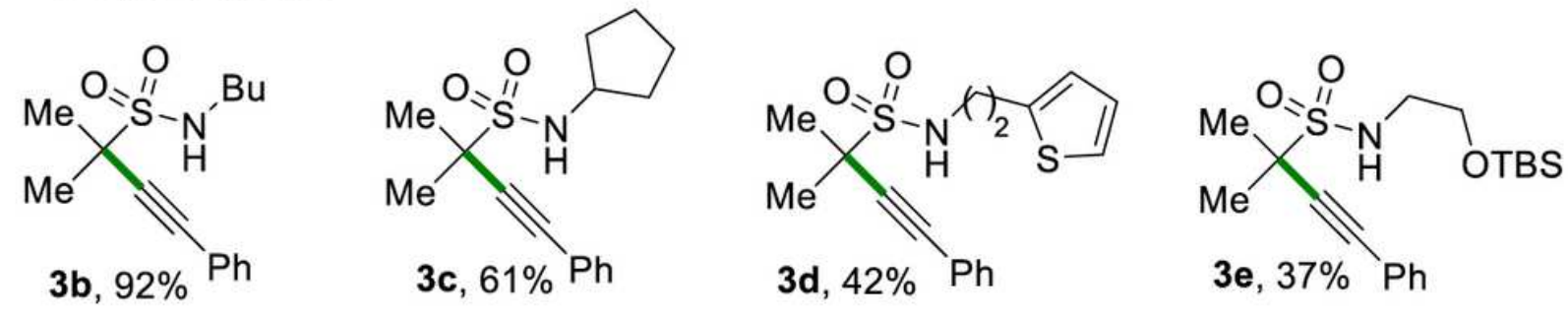

- Scope of sulfonyl
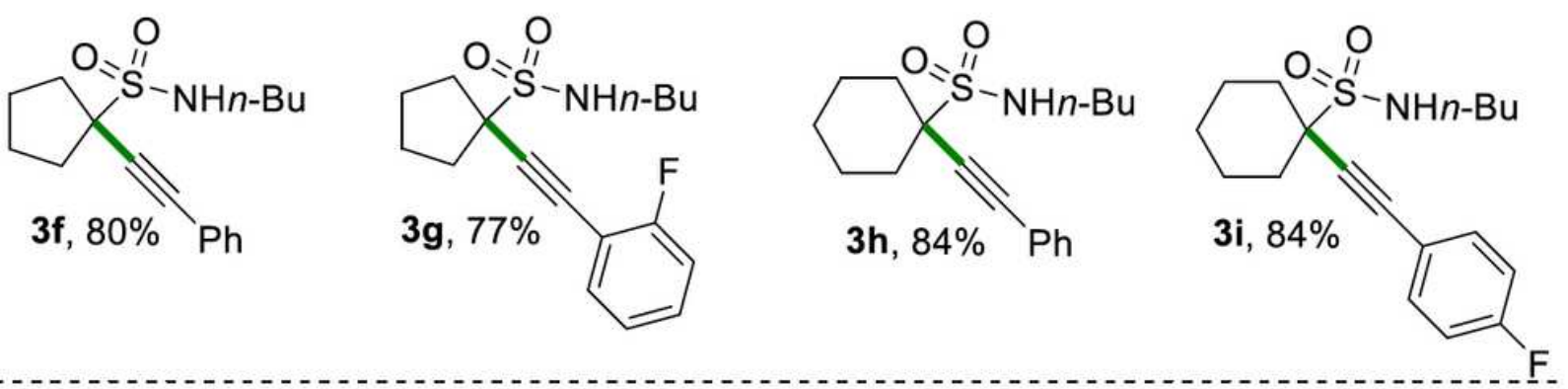

Scope of alkyne
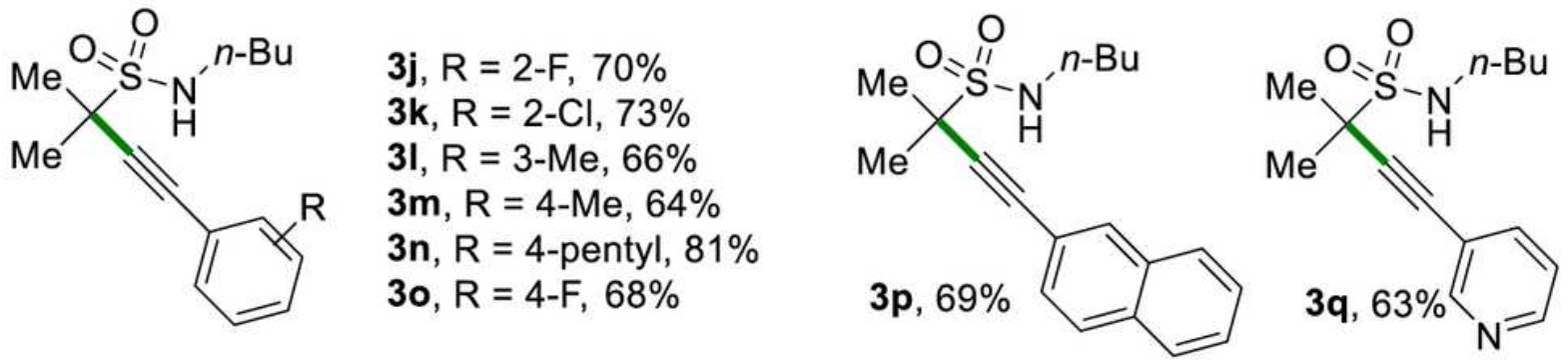

Figure 5

Scope of propargyl sulfonamides. Standard condition: 1 ( $0.2 \mathrm{mmol}), \operatorname{LDA}(0.3 \mathrm{mmol}), \mathrm{DMPU}(0.5 \mathrm{mmol})$, THF $(2 \mathrm{~mL}),-40 \mathrm{oC}, 1 \mathrm{hr}$, then treated with $\mathrm{MeOH}(0.1 \mathrm{~mL})$. Yields refer to isolated products. 
a) Gram-scale experiments

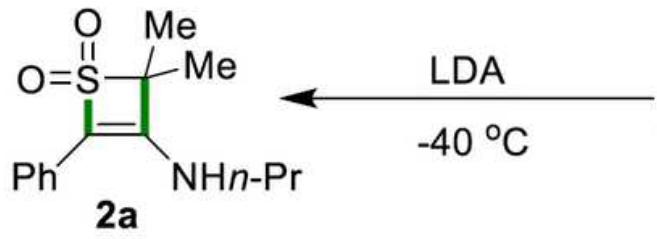

$74 \%(1.57 \mathrm{~g})$

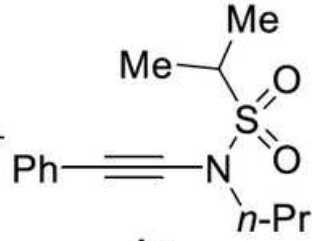

$1 \mathrm{a}$

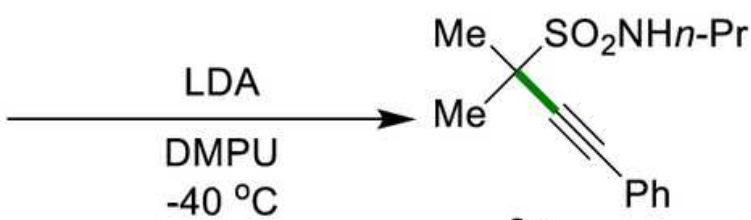

$3 a$

$8 \mathrm{mmol}$ scale

b) Electrophilic reagents-quenched reorganization toward $\boldsymbol{N}$-functionalized thiete sulfones<smiles>[R]C#CN([R])S(=O)(=O)C1CCCC1</smiles><smiles>[R]C1=C(N([R])C)C(CC)(CC)S1(=O)=O</smiles><smiles>[R]NC1=C(c2ccccc2)C(C)(C)S1(=O)=O</smiles>

4a, $\mathrm{R}=\mathrm{Me}, 71 \%$

$4 \mathrm{~b}, \mathrm{R}=$ allyl, $58 \%$

4c, $R=$ propargyl, $55 \%$<smiles>CC1(C)C(NCC[OH+][Sb])=C(c2ccccc2)S1(=O)=O</smiles>

4d, $60 \%$<smiles>C=C(CNC1=C(c2ccccc2)S(=O)(=O)C1(C)C)OCCC</smiles>

$4 e, 72 \%$<smiles>CC1(C)C(NCc2ccccc2)=C(c2ccccc2)S1(=O)=O</smiles>

4f, $56 \%$

c) Mel-quenched reorganization toward $\mathrm{N}$-methyl propargyl sulfonamide

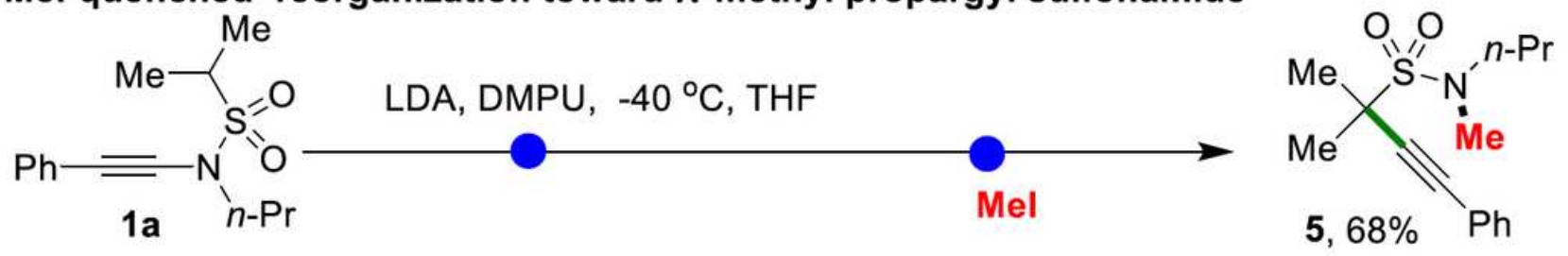

Figure 6

Synthetic applications. a. Gram-scale reaction. b. Electrophilic reagents-quenched reorganization toward $\mathrm{N}$-functionalized thiete sulfones, for details of electronic reagents, see Supplementary. c. Melquenched reorganization toward $\mathrm{N}$-methyl propargyl sulfonamide. 
a) Crossover experiment

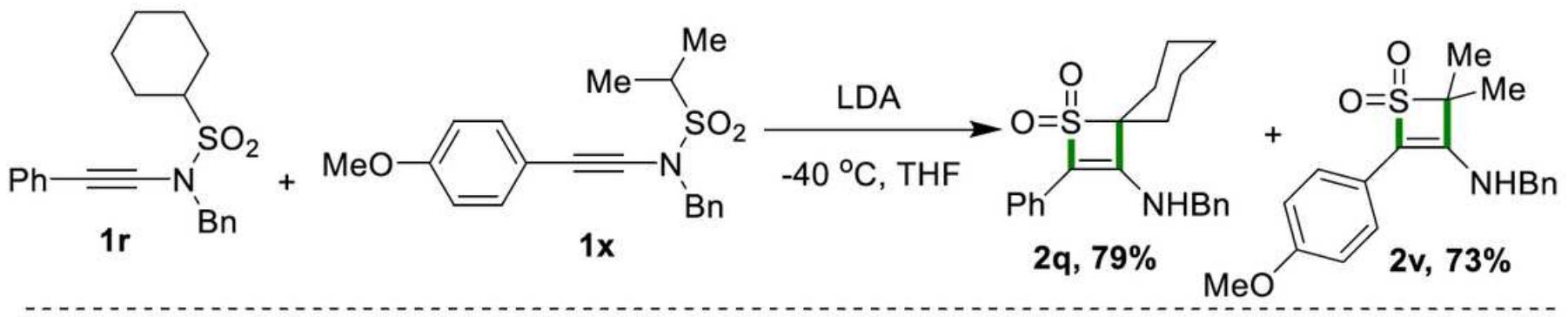

b) Reaction of $\mathrm{N}$-acetyl ynamide<smiles>CC(=O)N(C#CS[In])c1ccccc1</smiles>

$$
10^{\prime}
$$

6, $59 \%$

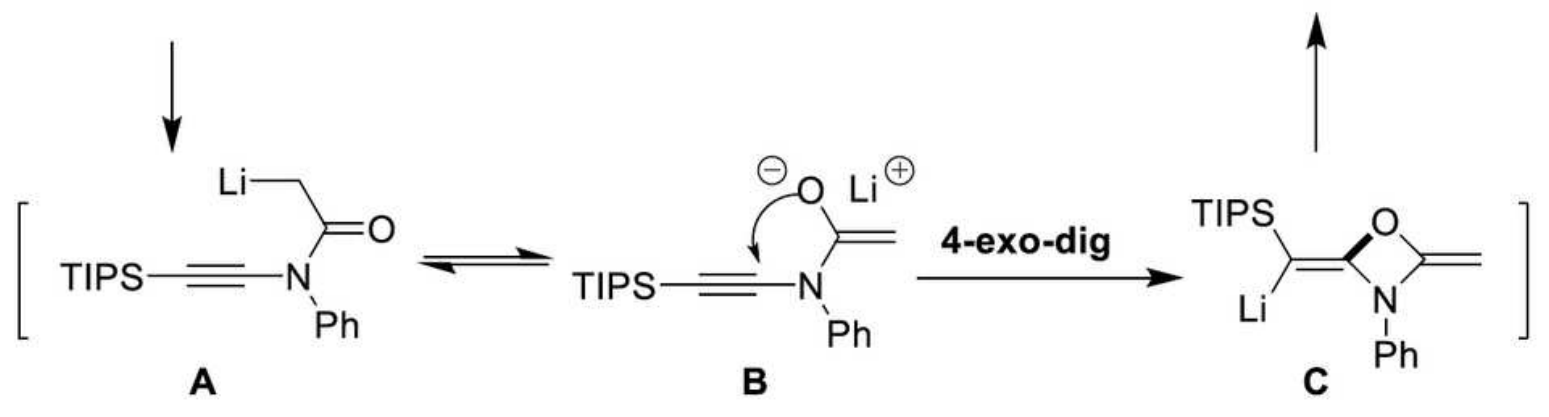

Figure 7

Mechanistic experiments. a. Crossover reaction. b. Reaction of N-acetyl ynamide.

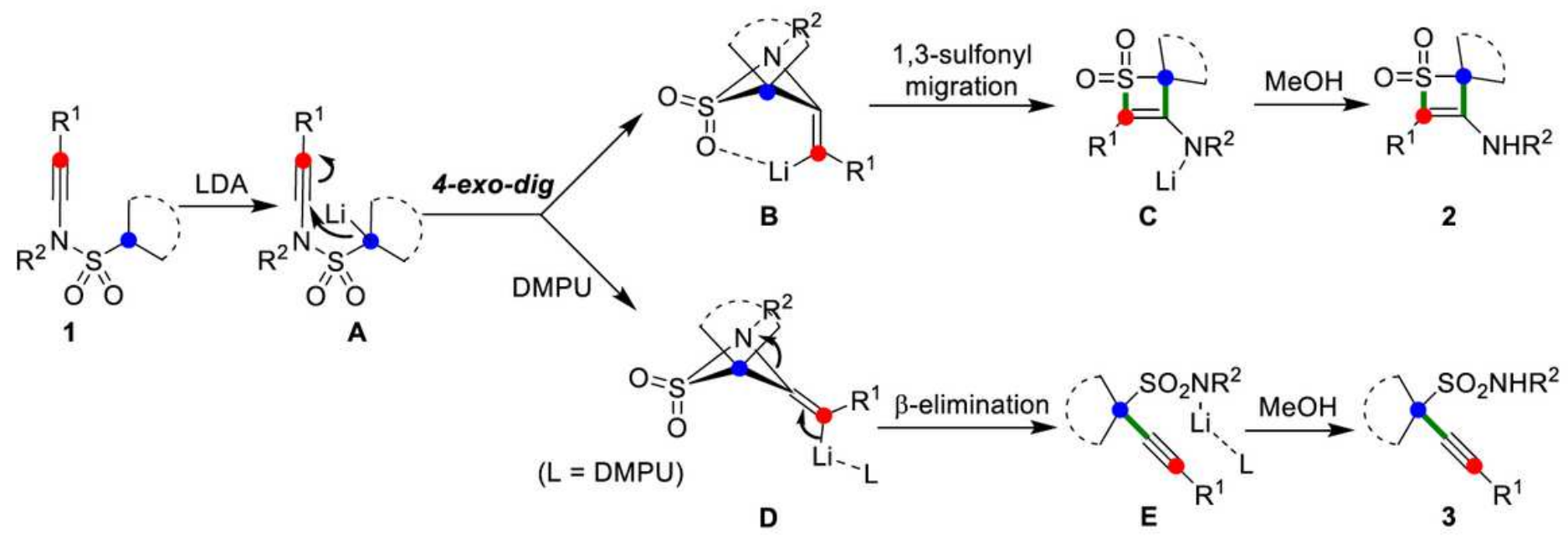

Figure 8

Plausible mechanism. 
This is a list of supplementary files associated with this preprint. Click to download.

- SINC.pdf 